Suuporting Information for

\title{
12/10-Helical $\beta$-Peptide with Dynamic Folding Propensity: Coexistence of Right- and Left-handed Helices in an Enantiomeric Foldamer
}

Seonho Shin, Mihye Lee, Ilia A. Guzei, Young Kee Kang and Soo Hyuk Choi

\section{Table of Contents}

Experimental Details and Characterization Data

Circular Dichroism \& NMR Experiments

S2

VT H-NMR Spectra

S3

Backbone Proton Chemical Shifts

S4

Two-dimensional NMR Experiments

S5

Medium-range NOEs and the corresponding $\mathrm{H}-\mathrm{H}$ distances

ROESY and TOCSY spectra

Crystallization and X-ray Structural Analysis

S8

Crystallization conditions and deposition numbers

Helical parameters

Backbone torsion angles

Crystal structure of 2

Crystal Structure Report

Compound 1

Compound 2

Compound 4

S15

Copies of High-resolution Mass Spectra

DFT Calculation

S20

Conformational analysis of three helical foldamers

Optimized structures

Calculated energies and relative populations

Cartesian coordinates of three helical foldamers

References

S28 


\section{Experimental details and characterization data}

General. 1-Ethyl-3-(3-dimethylaminopropyl)-carbodiimide (EDCI) were purchased from Chem-Impex International. Other reagents were purchased from Sigma-Aldrich, Alfa Aesar, Samchun Chemical, and TCI. Analytical thin-layer chromatography (TLC) was carried out on Pre-coated silica gel glass plate (Merck silica gel 60, F254, 0.25 mm). Silica gel 60 (230 240 mesh, Merck) was used for flash column chromatography. FT-IR spectra were recorded on Bruker Vertex 70 FT-IR spectrometer at 4000 $\mathrm{cm}^{-1} \sim 400 \mathrm{~cm}^{-1}$ of wave numbers. Mass spectra (MS) were acquired using an LTQ Orbitrap Spectrometer (ThermoFisher scientific

Inc.). $C i s-\mathrm{ACHC}^{\mathrm{S} 1}$ and cis,cis-mACHC ${ }^{\mathrm{S} 2}$ analogs were prepared by previously reported methods, respectively. $\beta$-peptides 1-4 were prepared by a standard solution-phase peptide synthesis with EDCI, HOBt, and TEA in DCM. Each peptide has the N-terminal Boc group and the C-terminal methyl ester or the methyl amide group.

Boc-[(1S,2R)-ACHC-(1R,2S)-ACHC]2-(1S,2R)-ACHC-OMe (1) ${ }^{1} \mathrm{H}$ NMR $\left(400 \mathrm{MHz}, \mathrm{CDCl}_{3}\right) \delta 7.81(\mathrm{~d}, J=9.2 \mathrm{~Hz}, 1 \mathrm{H}), 7.26(\mathrm{~s}$, $1 \mathrm{H}), 5.46(\mathrm{~s}, 1 \mathrm{H}), 4.77(\mathrm{~s}, 1 \mathrm{H}), 4.43(\mathrm{~s}, 2 \mathrm{H}), 4.25(\mathrm{~s}, 1 \mathrm{H}), 4.16(\mathrm{~s}, 1 \mathrm{H}), 3.71(\mathrm{~s}, 3 \mathrm{H}), 2.77(\mathrm{~s}, 1 \mathrm{H}), 2.70(\mathrm{~s}, 1 \mathrm{H}), 2.56(\mathrm{~m}, 2 \mathrm{H}), 2.52$ $(\mathrm{m}, 1 \mathrm{H}), 2.89-1.23(\mathrm{~m}, 49 \mathrm{H}) ;{ }^{13} \mathrm{C} \mathrm{NMR}\left(100 \mathrm{MHz}, \mathrm{CDCl}_{3}\right) \delta 176.3,173.8,173.5,172.6,156.1,79.3,52.2,49.0,48.0,46.3,30.4$, 28.5, 23.9, 21.5; HRMS $m / z$ calculated for $\mathrm{C}_{41} \mathrm{H}_{67} \mathrm{~N}_{5} \mathrm{NaO}_{8}{ }^{+}[\mathrm{M}+\mathrm{Na}]^{+} 780.4882$, found 780.4883 .

Boc-[(1S,2R)-ACHC-(1R, 2S)-ACHC]2-(1S,2R)-ACHC-NHMe (2) ${ }^{1} \mathrm{H}_{\mathbf{N M R}}\left(400 \mathrm{MHz}, \mathrm{CDCl}_{3}\right) \delta 7.90(\mathrm{~s}, 2 \mathrm{H}), 5.02-4.14(\mathrm{~m}$, $4 \mathrm{H}), 2.81(\mathrm{~s}, 3 \mathrm{H}), 2.62-2.56(\mathrm{~m}, 5 \mathrm{H}), 2.09-1.21(\mathrm{~m}, 49 \mathrm{H}) ;{ }^{13} \mathrm{C} \mathrm{NMR}\left(100 \mathrm{MHz}, \mathrm{CDCl}_{3}\right) \delta 175.5,173.8,173.7,172.6,156.0,79.3$, 72.4, 71.2, 61.7, 49.0, 46.3, 42.9, 29.7, 26.5, 23.6, 20.8; HRMS $m / z$ calculated for $\mathrm{C}_{41} \mathrm{H}_{68} \mathrm{~N}_{6} \mathrm{NaO}_{7}{ }^{+}\left[\mathrm{M}_{+} \mathrm{Na}^{+} 779.5042\right.$, found 779.5041 .

Boc-[(1S,2R)-ACHC-(1R,2S,4S)-mACHC]2-(1S,2R)-ACHC-NHMe (3) ${ }^{1} \mathrm{H}$ NMR (400 MHz, CDCl $\left.{ }_{3}\right) \delta 8.35(\mathrm{~d}, J=9.2 \mathrm{~Hz}, 1 \mathrm{H})$, $7.99(\mathrm{~d}, J=10.0 \mathrm{~Hz}, 1 \mathrm{H}), 7.90(\mathrm{~d}, J=10.4 \mathrm{~Hz}, 1 \mathrm{H}), 7.75(\mathrm{~d}, J=8.8 \mathrm{~Hz}, 1 \mathrm{H}), 6.56(\mathrm{~d}, J=4.4 \mathrm{~Hz}, 1 \mathrm{H}), 5.19(\mathrm{~d}, J=10.8 \mathrm{~Hz}, 1 \mathrm{H})$, $4.96(\mathrm{~d}, J=6.8 \mathrm{~Hz}, 1 \mathrm{H}), 4.66(\mathrm{~d}, J=6.0 \mathrm{~Hz}, 1 \mathrm{H}), 4.56(\mathrm{~d}, J=7.2 \mathrm{~Hz}, 1 \mathrm{H}), 4.15(\mathrm{~m}, 2 \mathrm{H}), 2.81(\mathrm{~s}, 1 \mathrm{H}), 2.77(\mathrm{~d}, J=4.8 \mathrm{~Hz}, 3 \mathrm{H})$, $2.64-2.40(\mathrm{~m}, 5 \mathrm{H}), 1.92-1.25(\mathrm{~m}, 46 \mathrm{H}), 0.89(\mathrm{~d}, J=6.4 \mathrm{~Hz}, 3 \mathrm{H}), 0.84(\mathrm{~d}, J=6.4 \mathrm{~Hz}, 3 \mathrm{H}) ;{ }^{13} \mathrm{C} \mathrm{NMR}\left(100 \mathrm{MHz}, \mathrm{CDCl}_{3}\right) \delta 175.7$, 174.0, 173.8, 173.7, 172.4, 156.2, 79.7, 77.4, 48.6, 48.3, 48.1, 47.4, 47.3, 46.7, 46.1, 45.7, 42.5, 42.0, 36.5, 32.6, 32.3, 31.4, 31.3, 30.6, 29.8, 29.7, 28.5, 28.0, 28.0, 26.9, 24.6, 24.5, 24.3; HRMS $m / z$ calculated for $\mathrm{C}_{47} \mathrm{H}_{72} \mathrm{~N}_{6} \mathrm{NaO}_{7}{ }^{+}\left[\mathrm{M}_{+} \mathrm{Na}\right]^{+} 807.5355$, found 807.5357

Boc-[(1S,2R,4R)-mACHC-(1R, 2S)-ACHC] $]_{2}-(\mathbf{1 S}, \mathbf{2} \boldsymbol{R}, \mathbf{4 R})-\mathbf{m A C H C}-\mathrm{NHMe}(\mathbf{4}){ }^{1} \mathrm{H}$ NMR $\left(400 \mathrm{MHz}_{\mathrm{C}} \mathrm{CDCl}_{3}\right) \delta 8.21(\mathrm{~d}, J=10.0$ $\mathrm{Hz}, 1 \mathrm{H}), 8.14(\mathrm{~d}, J=9.2 \mathrm{~Hz}, 1 \mathrm{H}), 7.87(\mathrm{~d}, J=4.0 \mathrm{~Hz}, 1 \mathrm{H}), 7.47(\mathrm{~d}, J=9.6 \mathrm{~Hz}, 1 \mathrm{H}), 6.08(\mathrm{~d}, J=10.0 \mathrm{~Hz}, 1 \mathrm{H}), 5.87(\mathrm{~d}, J=9.6 \mathrm{~Hz}$, $1 \mathrm{H}), 4.88(\mathrm{~d}, J=7.6 \mathrm{~Hz}, 1 \mathrm{H}), 4.44(\mathrm{~d}, J=6.8 \mathrm{~Hz}, 1 \mathrm{H}), 4.20(\mathrm{~m}, 1 \mathrm{H}), 4.02(\mathrm{~m}, 1 \mathrm{H}), 3.77(\mathrm{~m}, 1 \mathrm{H}), 2.83(\mathrm{~d}, J=4.8 \mathrm{~Hz}, 3 \mathrm{H}), 2.76(\mathrm{~s}$, $1 \mathrm{H}), 2.66(\mathrm{~s}, 1 \mathrm{H}), 2.57(\mathrm{~s}, 1 \mathrm{H}), 2.51(\mathrm{~m}, 1 \mathrm{H}), 2.22(\mathrm{~m}, 1 \mathrm{H}), 2.13-1.33(\mathrm{~m}, 46 \mathrm{H}), 0.94(\mathrm{~d}, J=6.0 \mathrm{~Hz}, 3 \mathrm{H}), 0.85(\mathrm{~d}, J=6.4 \mathrm{~Hz}, 3 \mathrm{H})$; ${ }^{13} \mathrm{C}$ NMR $\left(100 \mathrm{MHz} \mathrm{CDCl}_{3}\right) \delta 175.1,174.2,173.3,172.9,172.8,78.8,50.5,48.6,48.4,48.3,48.2,47.2$, 46.0, 45.7, 43.9, 42.7, $42.1,36.7,36.5,36.3,32.4,32.3,32.3,31.1,30.6,30.0,29.8,29.5,28.7,28.1,28.0,27.3$, 26.0; HRMS $\mathrm{m} / z$ calculated for $\mathrm{C}_{44} \mathrm{H}_{74} \mathrm{~N}_{6} \mathrm{NaO}_{7}[\mathrm{M}+\mathrm{Na}]^{+} 821.5511$, found 821.5513 .

\section{Circular Dichroism Experiment}

Circular Dichroism spectra were measured by using JASCO-815 spectrometer at 298K. The spectra were acquired using 1 -mm path length cell, wavelength range of 190 to $260 \mathrm{~nm}$ with $0.1 \mathrm{~nm}$ data interval, $1.0 \mathrm{~nm}$ bandwidth, and $200 \mathrm{~nm} / \mathrm{min}$ scanning speed. $\mathrm{CD}$ data were acquired by the background from the sample spectrum and smoothened over 25 data points. The final spectra were normalized for path length and concentration. The sample concentrations were $0.3 \mathrm{mM}$ in methanol or acetonitrile.

\section{NMR Experiments}

H-NMR and ${ }^{13} \mathrm{C}-\mathrm{NMR}$ spectra were recorded on a $400 \mathrm{MHz}$ FT-NMR Spectrometer (Bruker Biospin Avance $I I$ or Bruker Biospin Avance III HD 400). Variable temperature H-NMR spectra were acquired at $223 \sim 298 \mathrm{~K}$.

Two-dimensional NMR data were acquired at Korea Basic Science Institute (KBSI, Western Seoul branch). ROESY and TOCSY spectra of 3 and 4 in $\mathrm{CDCl}_{3}(10 \mathrm{mM})$ were recorded Varian UNITY INIVA 500 NMR spectrometer at 293 K. All resonance for each of peptides was assigned based on TOCSY data and sequential NOEs from ROESY data. 


\section{Solvent titration of $\mathrm{CDCl}_{3}$ solution with DMSO-d6}

Chemical shifts of the amide protons ( $\delta \mathrm{NHs}$ ) were measured while up to $250 \mu \mathrm{L}$ of DMSO- $\mathrm{d}_{6}$ was added sequentially to 500 $\mu \mathrm{L} \mathrm{CDCl}_{3}$ solution of $\beta$-peptides.

\section{VT H-NMR Spectra}

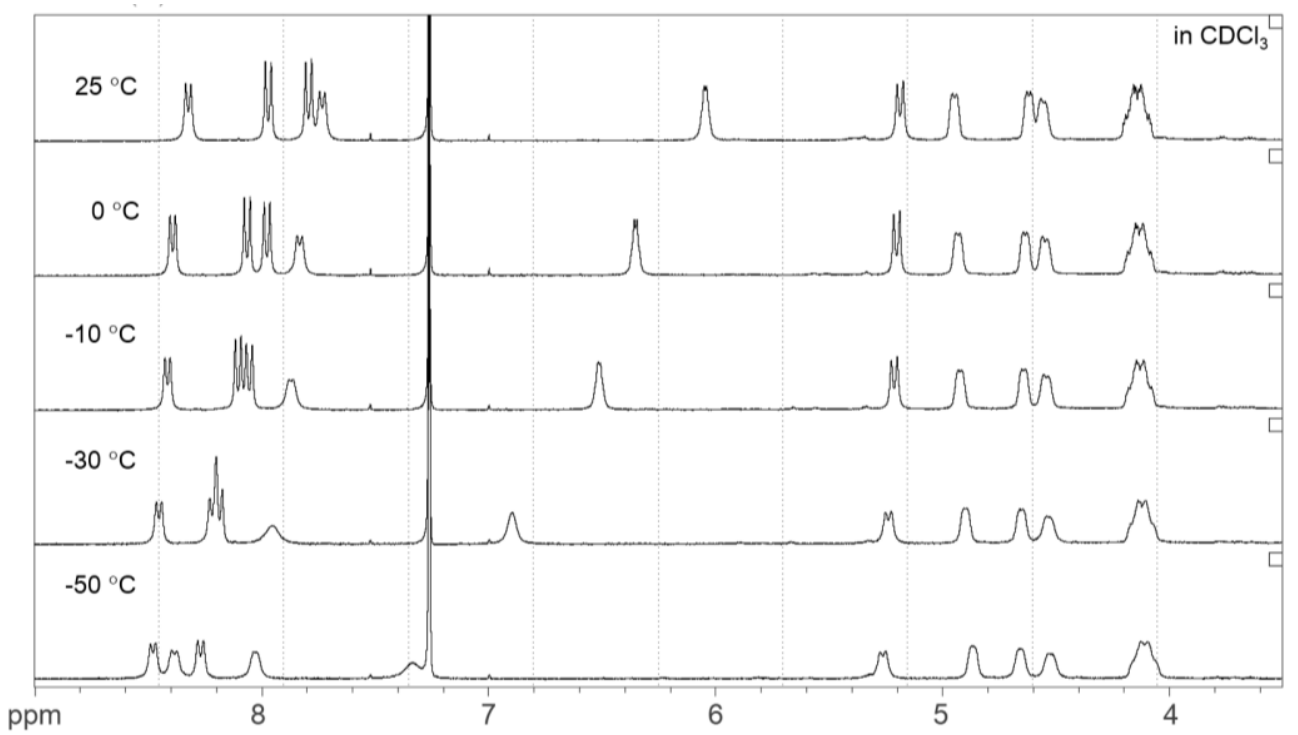

Figure S1. $\mathrm{H}-\mathrm{NMR}$ spectra for $\mathbf{3}$ in $\mathrm{CDCl}_{3}$ at various temperatures.

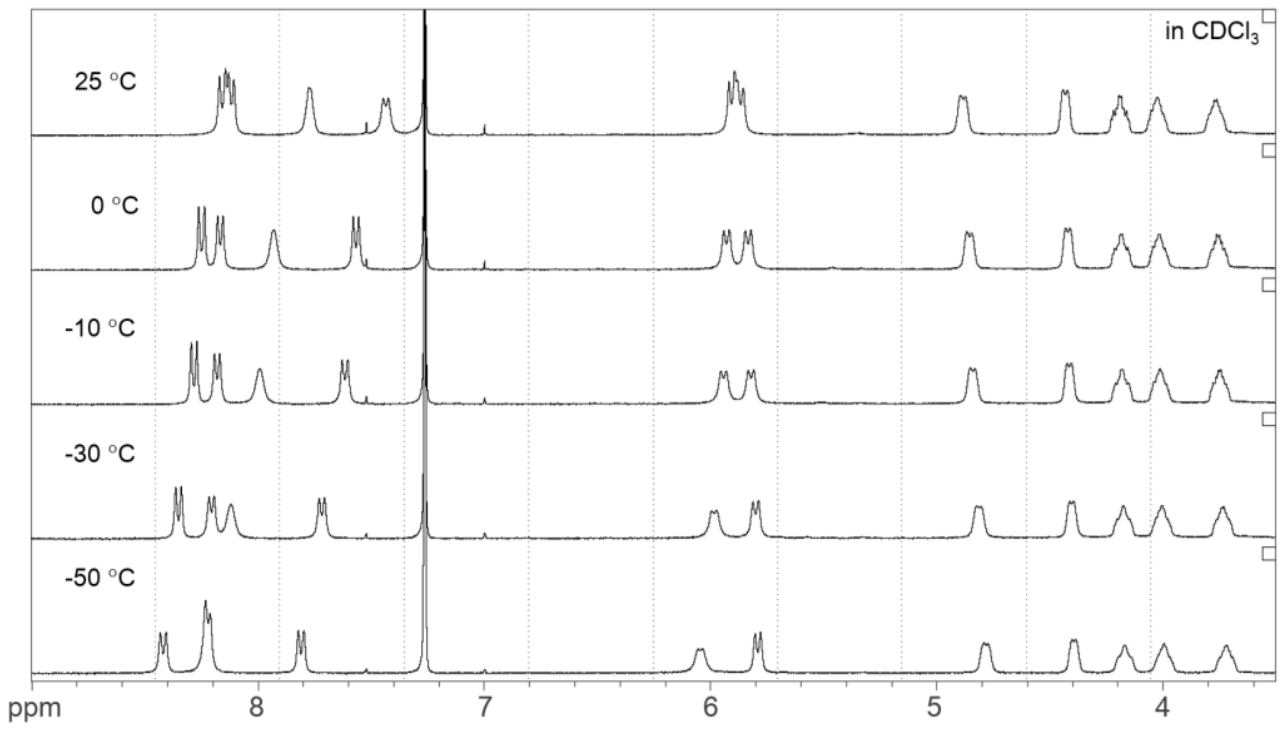

Figure S2. $\mathrm{H}-\mathrm{NMR}$ spectra for $\mathbf{4}$ in $\mathrm{CDCl}_{3}$ at various temperatures. 


\section{Backbone Proton Chemical Shifts}

Table S1. Backbone proton chemical shifts assigned for $\mathbf{3}$.

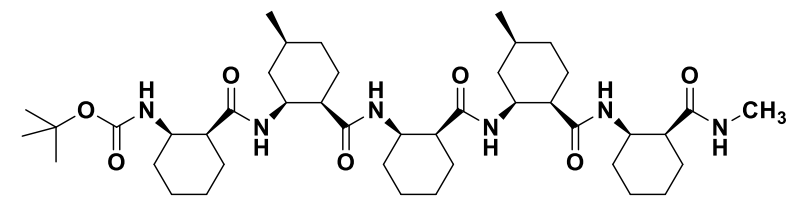

\begin{tabular}{cccccc}
\hline & $\mathrm{t}-\mathrm{Bu}$ & $\mathrm{H} \alpha$ & $\mathrm{H} \beta$ & $\mathrm{NH}$ & Methyl \\
\hline N-term & 1.42 & - & - & - & - \\
Residue1 & - & 2.58 & 4.56 & 5.19 & - \\
Residue2 & - & 2.55 & 4.16 & 7.99 & 0.83 \\
Residue3 & - & 1.69 & 4.94 & 7.76 & - \\
Residue4 & - & 2.81 & 4.12 & 7.81 & 0.90 \\
Residue5 & - & 2.39 & 4.63 & 8.34 & - \\
C-term & - & - & - & 5.98 & 2.80 \\
\hline
\end{tabular}

Table S2. Backbone proton chemical shifts assigned for 4.

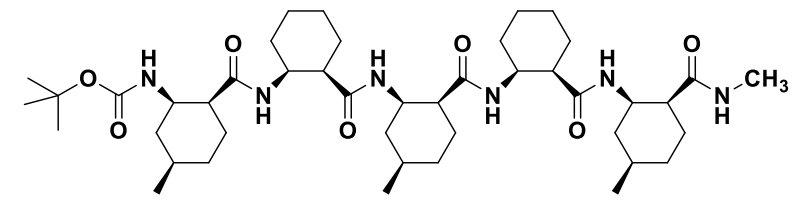

\begin{tabular}{cccccc}
\hline & $\mathrm{t}-\mathrm{Bu}$ & $\mathrm{Ha}$ & $\mathrm{H} \beta$ & $\mathrm{NH}$ & Methyl \\
\hline N-term & 1.48 & - & - & - & - \\
Residue1 & - & 2.57 & 3.77 & 7.47 & 0.85 \\
Residue2 & - & 2.48 & 4.90 & 5.86 & - \\
Residue3 & - & 2.66 & 4.19 & 8.18 & 0.85 \\
Residue4 & - & 2.20 & 4.43 & 8.14 & - \\
Residue5 & - & 2.78 & 4.03 & 5.91 & 0.94 \\
C-term & - & - & - & 7.80 & 2.83 \\
\hline
\end{tabular}




\section{Medium-range NOEs and the corresponding $\mathrm{H}-\mathrm{H}$ distances}

(a) $\mathrm{H}-\mathrm{H}$ distances measured from the crystal structure of 2 ( $M$-helix)
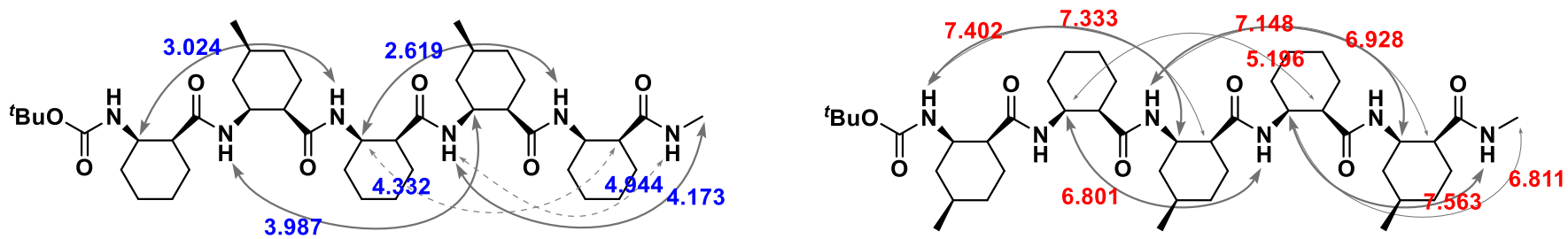

(b) $\mathrm{H}-\mathrm{H}$ distances measured from the crystal structure of 4 ( $P$-helix)
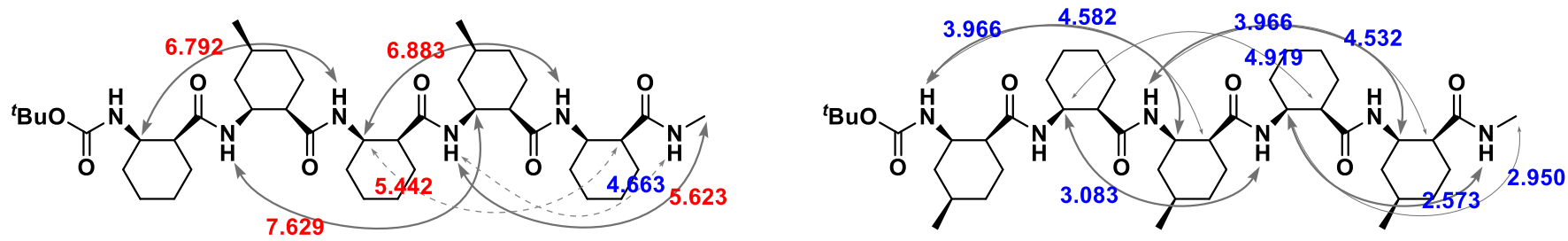

Figure S3. Comparison of medium-range backbone NOEs and the corresponding inter-proton distances in crystal structures of (a) 2 and (b) 4. Arrows indicate observed medium-range NOEs. Dashed arrows indicate weak and ambiguous NOEs. Numbers indicate inter-proton distances within $5 \AA$ (blue) or over $5 \AA$ (red). 


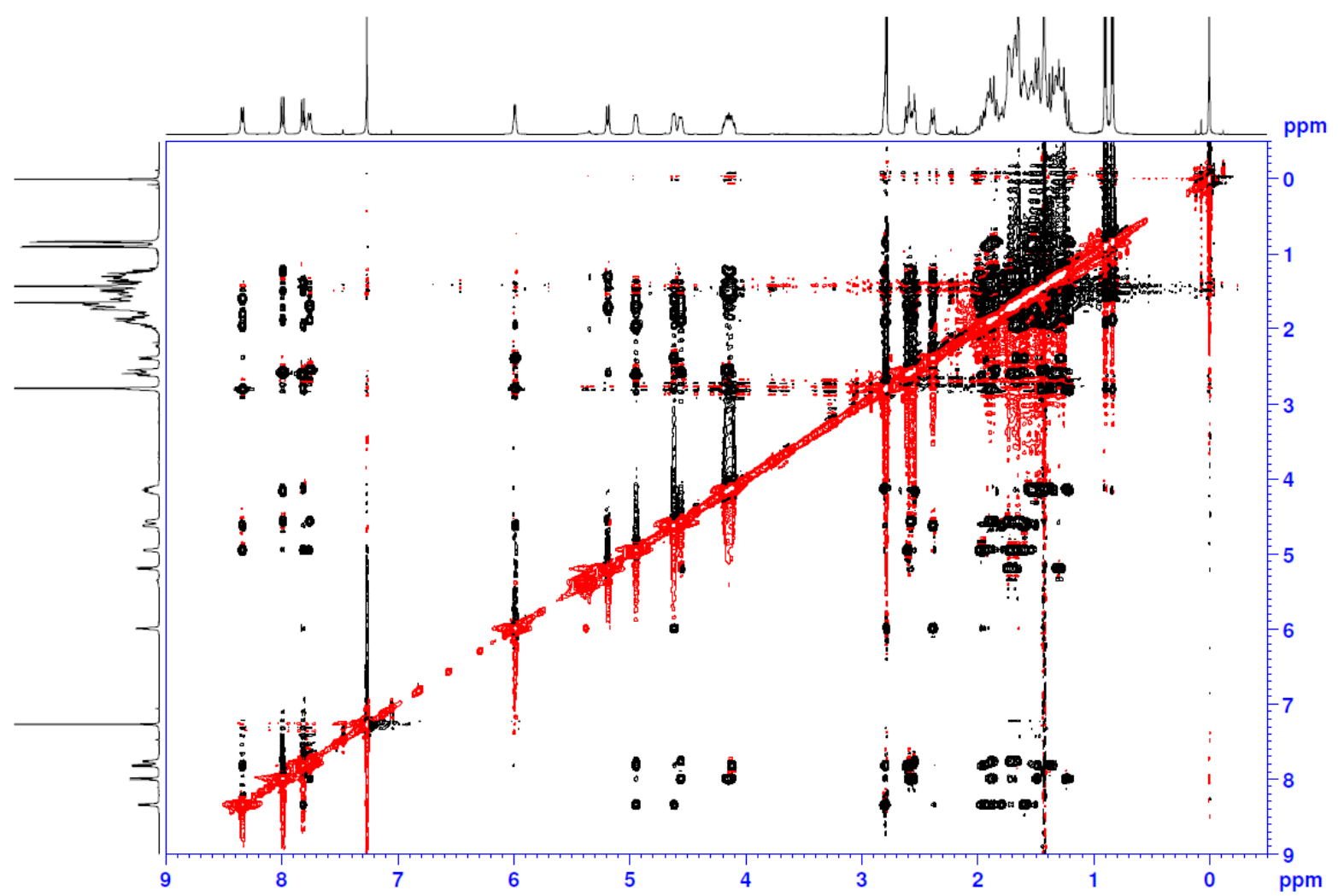

Figure S4. ROESY spectrum for 3 in $\mathrm{CDCl}_{3}$.

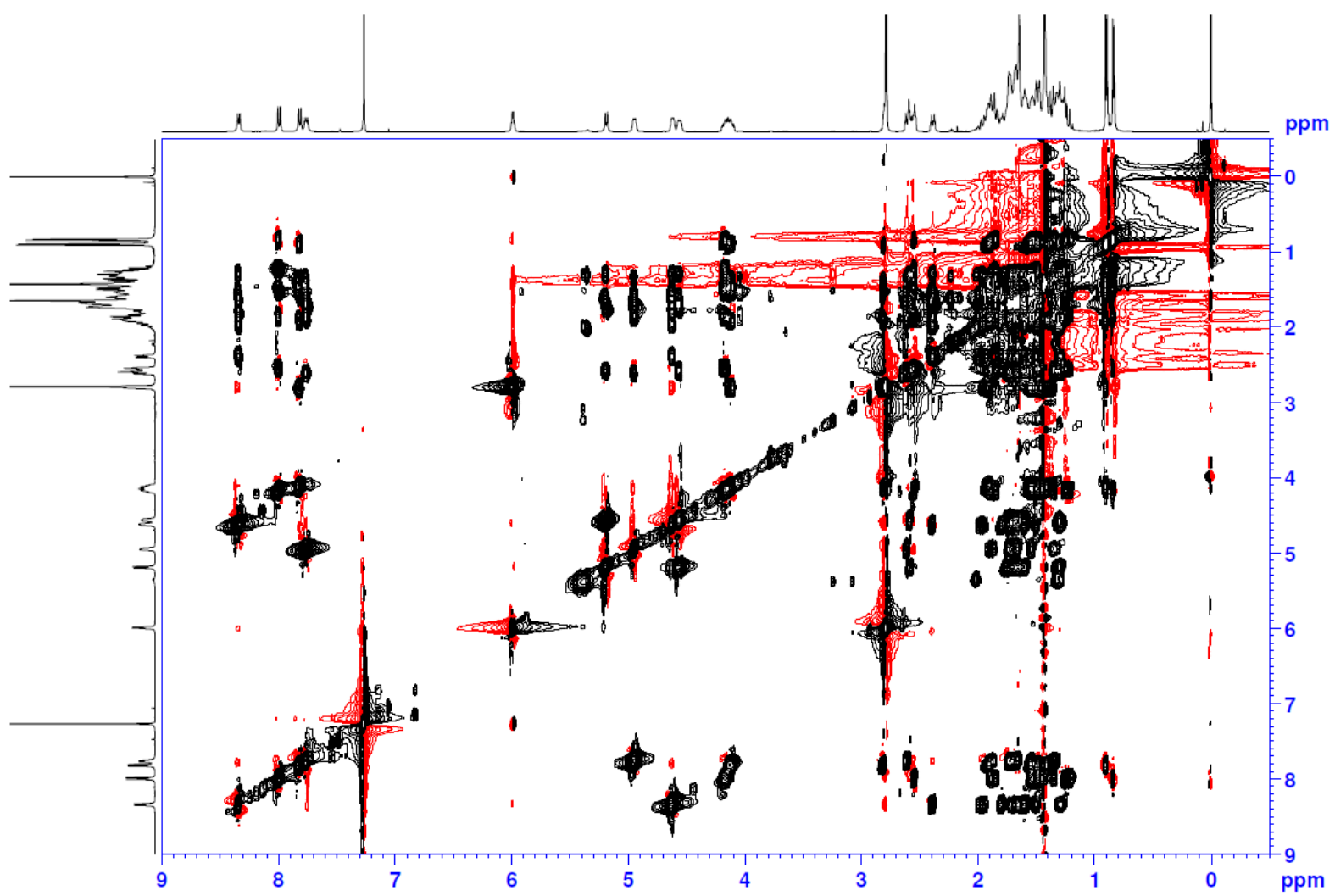

Figure S5. TOCSY spectrum for 3 in $\mathrm{CDCl}_{3}$. 


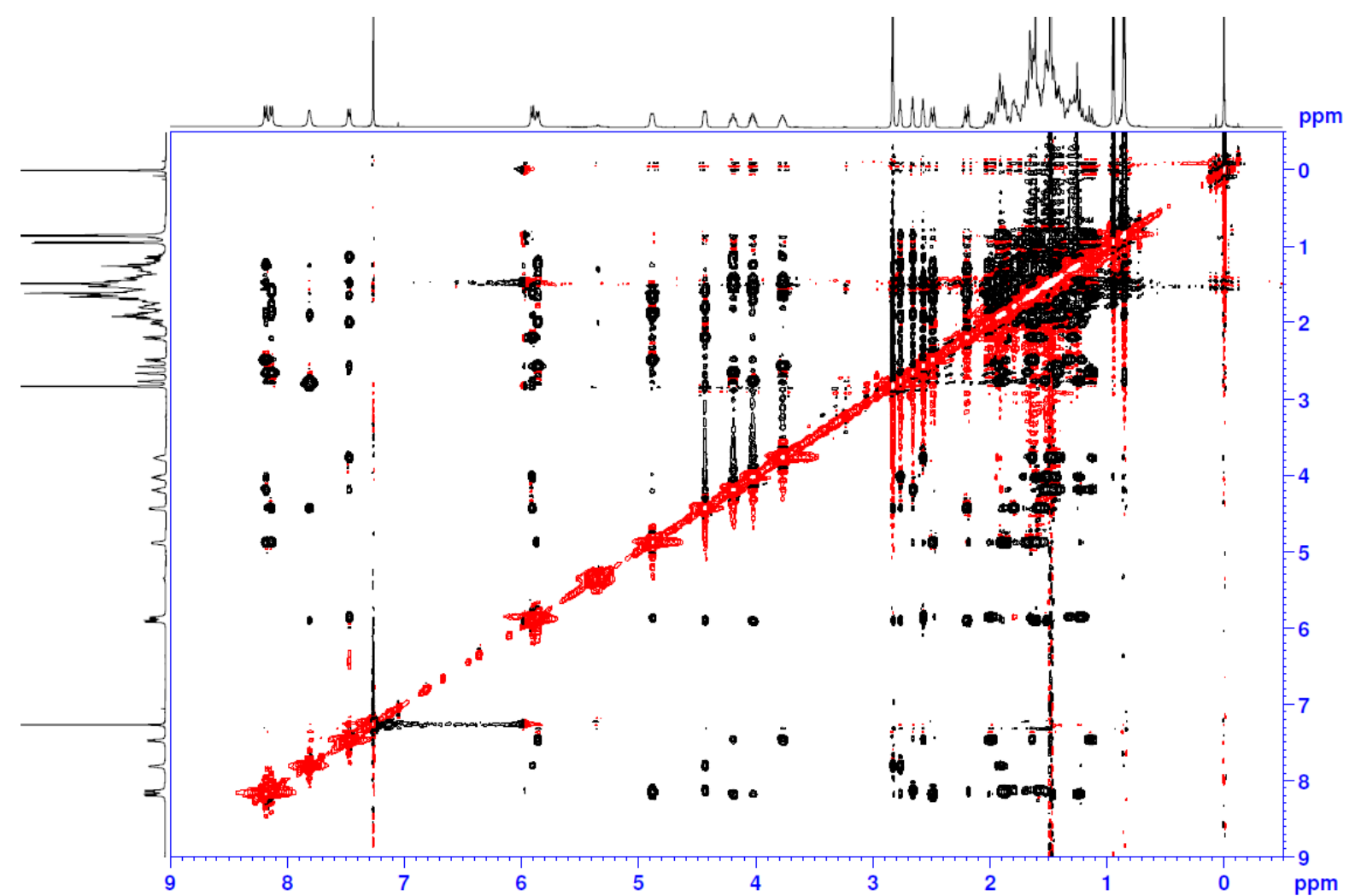

Figure S6. ROESY spectrum for $\mathbf{4}$ in $\mathrm{CDCl}_{3}$.

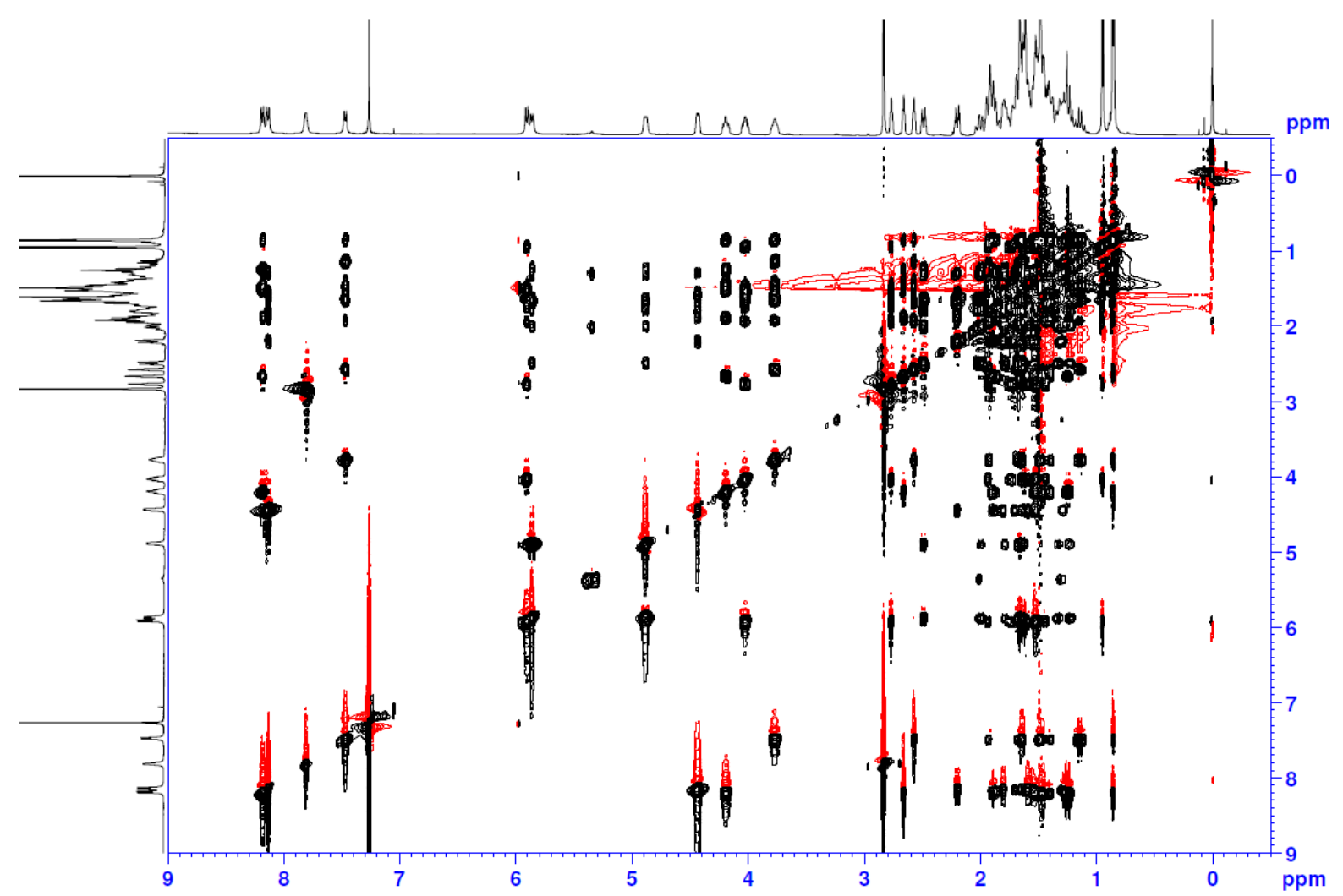

Figure S7. TOCSY spectrum for 4 in $\mathrm{CDCl}_{3}$. 


\section{Crystallization and X-ray structural analysis}

Table S3. Crystallization conditions and CCDC deposition numbers.

\begin{tabular}{ccl}
\hline CCDC number $^{a}$ & compound & \multicolumn{1}{c}{ crystallization condition } \\
\hline 1486358 & rac $-\mathbf{1}$ & Solvent diffusion $\left(\mathrm{CHCl}_{3} / n\right.$-pentane $)$ \\
1486359 & $\mathbf{2}$ & Solvent diffusion $\left(\mathrm{CHCl}_{3} / \mathrm{Et}_{2} \mathrm{O} / n\right.$-pentane $)$ \\
1486360 & $\mathbf{4}$ & Solvent diffusion $\left(\mathrm{CHCl}_{3} / \mathrm{Et}_{2} \mathrm{O} / n\right.$-pentane $)$ \\
\hline
\end{tabular}

a. Deposition number at the Cambridge Crystallographic Data Centre (CCDC).

Table S4. Helical Parameters for the 12/10-helix calculated from every set of four consecutive $\alpha$-carbons.

\begin{tabular}{ccccc}
\hline compound & $\begin{array}{c}\text { residue- } \\
\text { per-turn } \\
n(\AA)\end{array}$ & $\begin{array}{c}\text { rise-per-turn } \\
p(\AA)\end{array}$ & $\begin{array}{c}\text { rise-per- } \\
\text { residue } \\
d(\AA)\end{array}$ & $\begin{array}{c}\text { radius } \\
r(\AA)\end{array}$ \\
\hline \multirow{2}{*}{$\mathbf{1}$} & 2.5 & 5.8 & 2.3 & 2.0 \\
& 2.6 & 5.7 & 2.2 & 2.1 \\
\hline \multirow{2}{*}{$\mathbf{2}$} & 2.7 & 5.8 & 2.2 & 2.1 \\
& 2.6 & 5.6 & 2.1 & 2.1 \\
\hline \multirow{2}{*}{4} & 2.5 & 5.8 & 2.3 & 2.0 \\
& 2.5 & 5.9 & 2.4 & 1.9 \\
\hline average & $\mathbf{2 . 6}$ & $\mathbf{5 . 7}$ & $\mathbf{2 . 2}$ & $\mathbf{2 . 0}$ \\
\hline
\end{tabular}

Table S5. Backbone torsion angles of the 12/10-helical structures.

\begin{tabular}{ccccc}
\hline \multirow{2}{*}{ compound } & \multirow{2}{*}{ residue } & \multicolumn{3}{c}{ Torsion angle (degree) } \\
\cline { 3 - 5 } & & $\phi$ & $\theta$ & $\psi$ \\
\hline \multirow{3}{*}{1} & ACHC1 & 126.40 & -51.59 & -71.69 \\
& ACHC2 & -119.19 & -58.89 & 93.02 \\
& ACHC3 & 91.13 & -49.89 & -101.35 \\
& ACHC4 & -100.34 & -57.38 & 103.47 \\
& ACHC5 & 92.75 & -54.60 & -87.69 \\
\hline \multirow{2}{*}{$\mathbf{2}$} & ACHC1 & 112.15 & -59.18 & -57.11 \\
& ACHC2 & -133.37 & -57.99 & 106.47 \\
& ACHC3 & 100.92 & -57.12 & -84.94 \\
& ACHC4 & -103.98 & -60.65 & 75.50 \\
& ACHC5 & 147.20 & -56.02 & -135.77 \\
\hline \multirow{2}{*}{4} & mACHC1 & 83.43 & 55.18 & -83.27 \\
& ACHC2 & -91.85 & 47.82 & 96.78 \\
& mACHC3 & 107.28 & 57.66 & -89.55 \\
& ACHC4 & -99.53 & 56.44 & 93.87 \\
& mACHC5 & 103.44 & 49.30 & -104.00 \\
\hline
\end{tabular}



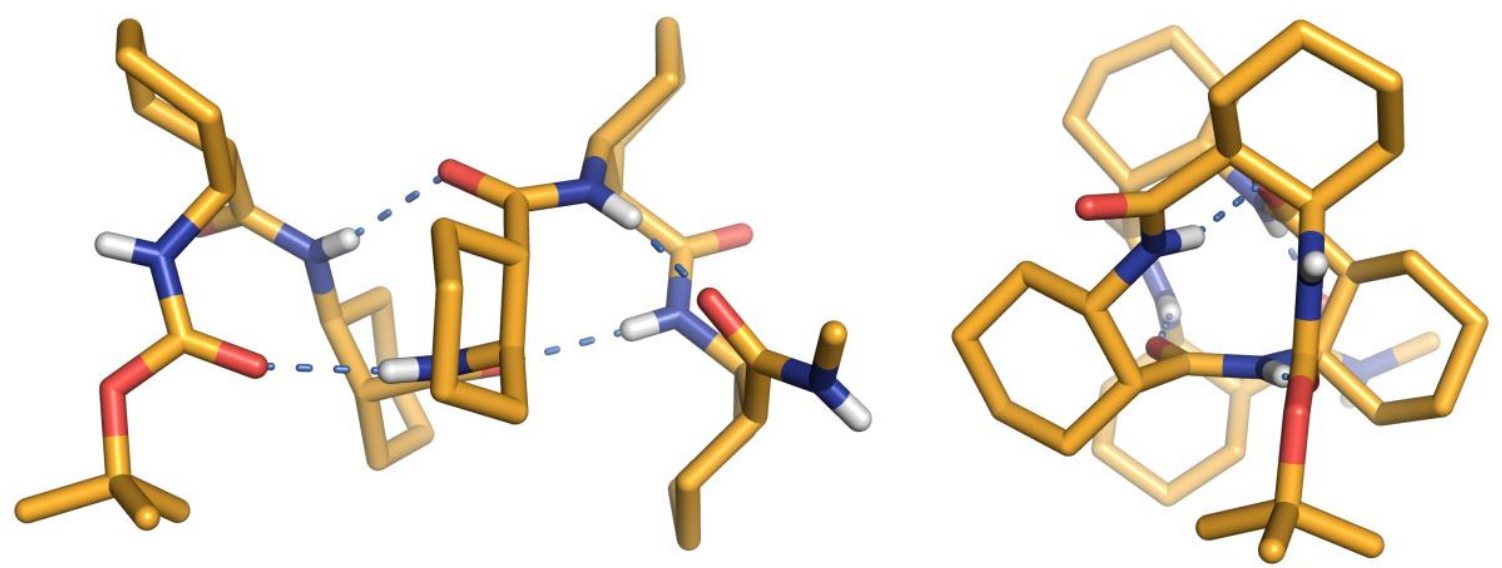

Figure S8. Crystal structure of 2 viewed perpendicular (left) and parallel (right) to the helical axis. Dashed lines indicate intramolecular hydrogen bonds. 


\section{Crystal structure report}

\section{- Pentamers rac-1 (1+ent-1)}

\section{Data Collection}

A colorless crystal with approximate dimensions $0.38 \times 0.19 \times 0.09 \mathrm{~mm}^{3}$ was selected under oil under ambient conditions and attached to the tip of a MiTeGen MicroMount $\odot$. The crystal was mounted in a stream of cold nitrogen at 100(1) K and centered in the X-ray beam by using a video camera.

The crystal evaluation and data collection were performed on a Bruker Quazar SMART APEXII diffractometer with Mo $\mathrm{K}_{\alpha}(\lambda=0.71073 \AA)$ radiation and the diffractometer to crystal distance of $4.96 \mathrm{~cm}$.

The initial cell constants were obtained from three series of $\omega$ scans at different starting angles. Each series consisted of 12 frames collected at intervals of $0.5^{\circ}$ in a $6^{\circ}$ range about $\omega$ with the exposure time of 3 seconds per frame. The reflections were successfully indexed by an automated indexing routine built in the APEXII program suite. The final cell constants were calculated from a set of 9821 strong reflections from the actual data collection.

The data were collected by using the full sphere data collection routine to survey the reciprocal space to the extent of a full sphere to a resolution of $0.70 \AA$ A. A total of 99732 data were harvested by collecting 6 sets of frames with $0.5^{\circ}$ scans in $\omega$ and $\varphi$ with exposure times of $40 \mathrm{sec}$ per frame. These highly redundant datasets were corrected for Lorentz and polarization effects. The absorption correction was based on fitting a function to the empirical transmission surface as sampled by multiple equivalent measurements. ${ }^{\mathrm{s} 3}$

\section{Structure Solution and Refinement}

The systematic absences in the diffraction data were consistent for the space groups $P \overline{1}$ and $P 1$. The $E$-statistics strongly suggested the centrosymmetric space group $P \overline{1}$ that yielded chemically reasonable and computationally stable results of refinement. ${ }^{[\mathrm{S4}-6] \mathrm{S} 4}$

A successful solution by the direct methods provided most non-hydrogen atoms from the $E$-map. The remaining nonhydrogen atoms were located in an alternating series of least-squares cycles and difference Fourier maps. All non-hydrogen atoms were refined with anisotropic displacement coefficients. All aliphatic hydrogen atoms were included in the structure factor calculation at idealized positions and were allowed to ride on the neighboring atoms with relative isotropic displacement coefficients. All amide $\mathrm{H}$ atoms were refined independently.

There were also solvent molecules present in the asymmetric unit. There were two positions for these molecules at crystallographic inversion centers; these molecules were positionally and compositionally disordered. A significant amount of time was invested in identifying and refining the disordered molecules. Bond length restraints were applied to model the molecules but the resulting isotropic displacement coefficients suggested the molecules were mobile. In addition, the refinement was computationally unstable. Option SQUEEZE of program PLATON ${ }^{55}$ was used to correct the diffraction data for diffuse scattering effects and to identify the solvate molecule. PLATON calculated the upper limit of volume that can be occupied by the solvent to be $560 \AA^{3}$, or $12 \%$ of the unit cell volume. The program calculated 77 electrons in the unit cell for the diffuse species. This approximately corresponds to a molecule of $\mathrm{CHCl}_{3}$ and a molecule of pentane, each occupied at $77 \%$. Note that all derived results in the following tables are based on the known contents - these two solvents were used, but their exact ratio in the crystal is unknown. No data are given for the diffusely scattering species.

The final least-squares refinement of 1021 parameters against 18605 data resulted in residuals $R$ (based on $F^{2}$ for $I \geq 2 \sigma$ ) and $w R$ (based on $F^{2}$ for all data) of 0.0391 and 0.1074 , respectively. The final difference Fourier map was featureless.

\section{Summary}

Crystal Data for $\mathrm{C}_{41} \mathrm{H}_{67} \mathrm{~N}_{5} \mathrm{O}_{8}(M=757.99 \mathrm{~g} / \mathrm{mol})$ : triclinic, space group P-1 (no. 2), $a=12.826(4) \AA, b=16.245(5) \AA, c=$ 21.953(6) $\AA, \alpha=89.214(12)^{\circ}, \beta=89.300(15)^{\circ}, \gamma=89.609(13)^{\circ}, V=4573(2) \AA^{3}, Z=4, T=100.01 \mathrm{~K}, \mu(\mathrm{MoK} \alpha)=0.076 \mathrm{~mm}$ ${ }^{1}$, Dcalc $=1.101 \mathrm{~g} / \mathrm{cm}^{3}, 99732$ reflections measured $\left(2.508^{\circ} \leq 2 \Theta \leq 52.806^{\circ}\right), 18605$ unique $\left(R_{\text {int }}=0.0284, \mathrm{R}_{\text {sigma }}=0.0200\right)$ which were used in all calculations. The final $R_{1}$ was 0.0391 (I $\left.>2 \sigma(\mathrm{I})\right)$ and $w R_{2}$ was 0.1074 (all data). 


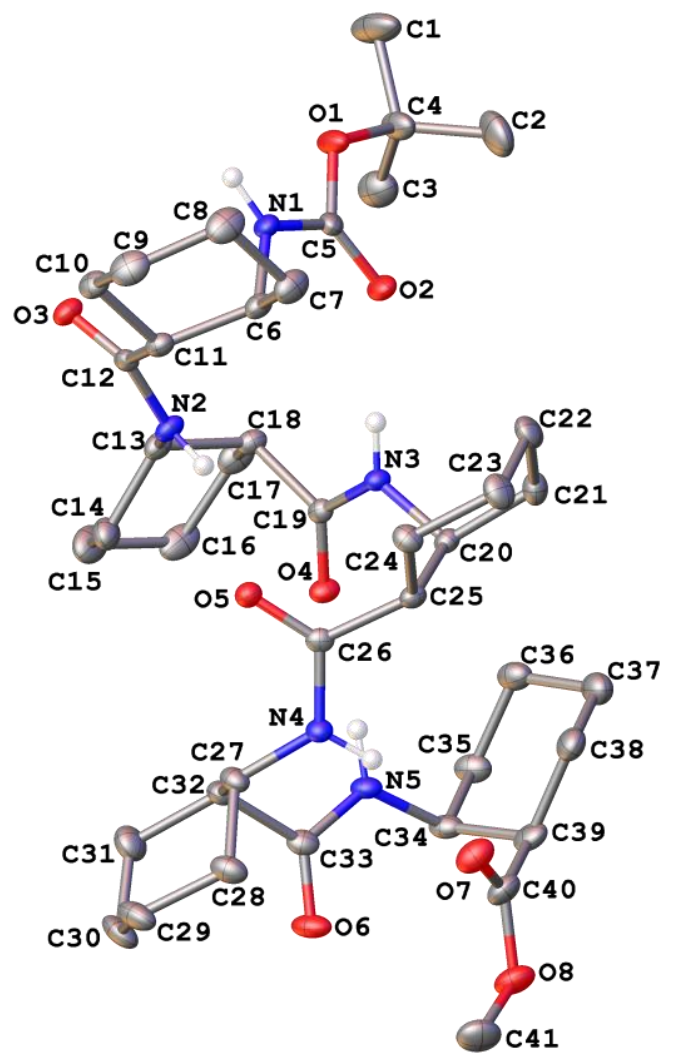

Figure S9. A drawing of the first symmetry-independent molecule of ent-1 shown with 50\% probability ellipsoids. All aliphatic $\mathrm{H}$ atoms are omitted.

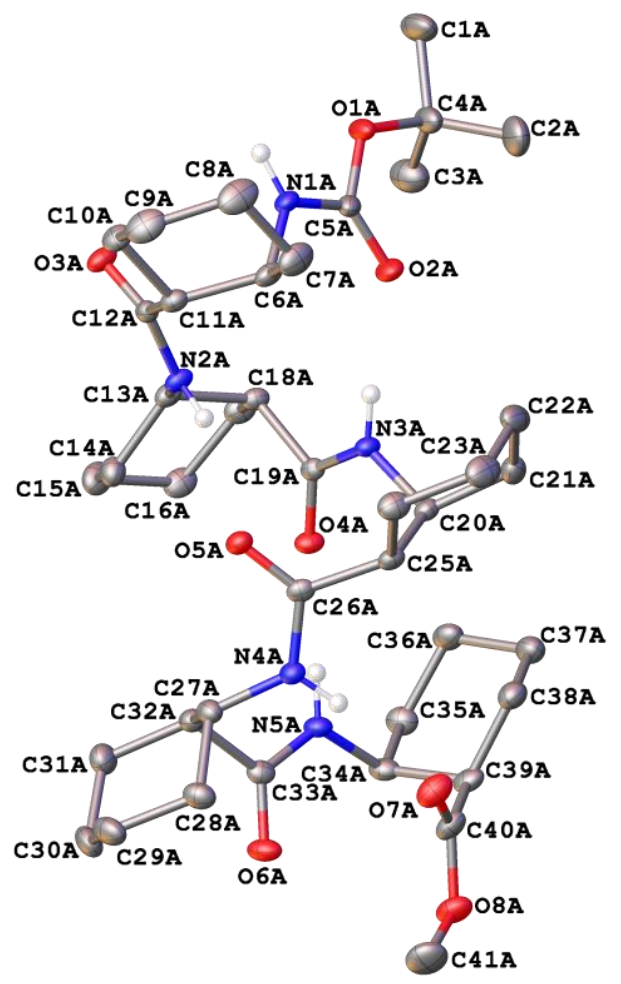

Figure S10. A drawing of the second symmetry-independent molecule of ent-1 shown with $50 \%$ probability ellipsoids. All aliphatic $\mathrm{H}$ atoms are omitted. 


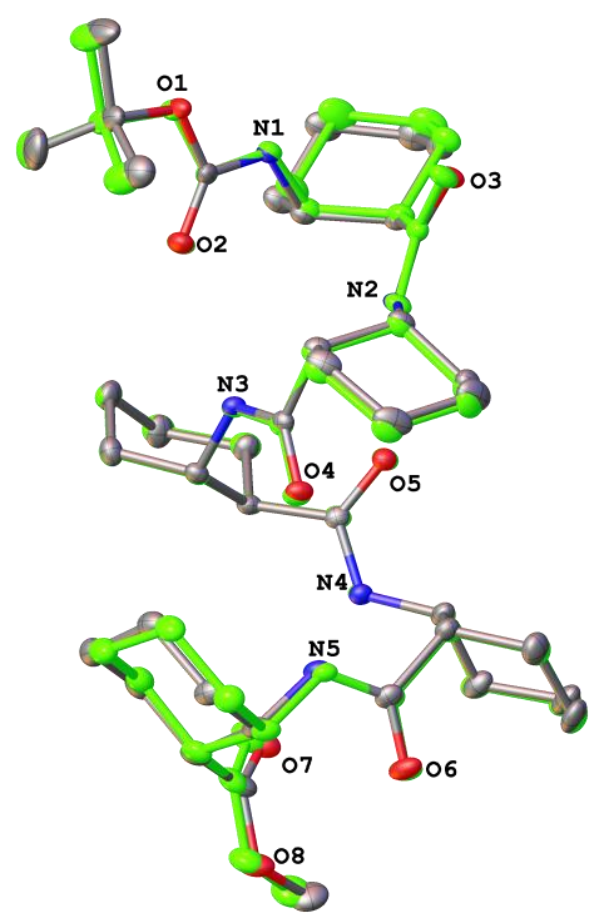

Figure S11. A drawing of superimposed symmetry-independent molecules of ent-1 shown with $50 \%$ probability ellipsoids. All $\mathrm{H}$ atoms are omitted.

Table S6. Crystal data and structure refinement for $r a c-1$

\begin{tabular}{|c|c|}
\hline Empirical formula & $\mathrm{C}_{41} \mathrm{H}_{67} \mathrm{~N}_{5} \mathrm{O}_{8} \times$ Solvent \\
\hline Formula weight & 757.99 \\
\hline Temperature/K & 100.01 \\
\hline Crystal system & triclinic \\
\hline Space group & $\mathrm{P} \overline{1}$ \\
\hline $\mathrm{a} / \AA ̊$ & $12.826(4)$ \\
\hline $\mathrm{b} / \AA$ & $16.245(5)$ \\
\hline $\mathrm{c} / \AA$ & $21.953(6)$ \\
\hline$\alpha /^{\circ}$ & $89.214(12)$ \\
\hline$\beta /{ }^{\circ}$ & $89.300(15)$ \\
\hline$\gamma /{ }^{\circ}$ & $89.609(13)$ \\
\hline Volume $/ \AA^{3}$ & $4573(2)$ \\
\hline $\mathrm{Z}$ & 4 \\
\hline$\rho_{\text {calc }} \mathrm{g} / \mathrm{cm}^{3}$ & 1.101 \\
\hline$\mu / \mathrm{mm}^{-1}$ & 0.076 \\
\hline $\mathrm{F}(000)$ & 1648.0 \\
\hline Crystal size $/ \mathrm{mm}^{3}$ & $0.38 \times 0.19 \times 0.09$ \\
\hline Radiation & $\operatorname{MoK} \alpha(\lambda=0.71073)$ \\
\hline \multicolumn{2}{|c|}{$2 \Theta$ range for data collection $/{ }^{\circ} 2.508$ to 52.806} \\
\hline Index ranges & $-16 \leq \mathrm{h} \leq 15,-20 \leq \mathrm{k} \leq 20,-27 \leq 1 \leq 27$ \\
\hline Reflections collected & 99732 \\
\hline Independent reflections & $18605\left[R_{\text {int }}=0.0284, R_{\text {sigma }}=0.0200\right]$ \\
\hline Data/restraints/parameters & $18605 / 0 / 1021$ \\
\hline Goodness-of-fit on $\mathrm{F}^{2}$ & 1.025 \\
\hline Final $\mathrm{R}$ indexes $[\mathrm{I}>=2 \sigma(\mathrm{I})]$ & $\mathrm{R}_{1}=0.0391, \mathrm{wR}_{2}=0.1020$ \\
\hline Final $\mathrm{R}$ indexes [all data] & $\mathrm{R}_{1}=0.0467, \mathrm{wR}_{2}=0.1074$ \\
\hline Largest diff. peak/hole / e $\AA^{-3}$ & $0.35 /-0.22$ \\
\hline
\end{tabular}




\section{- Pentamer 2}

\section{Data Collection}

A colorless crystal with approximate dimensions $0.254 \times 0.104 \times 0.054 \mathrm{~mm}^{3}$ was selected under oil under ambient conditions and attached to the tip of a MiTeGen MicroMount $\odot$. The crystal was mounted in a stream of cold nitrogen at $100(1) \mathrm{K}$ and centered in the X-ray beam by using a video camera.

The crystal evaluation and data collection were performed on a Bruker SMART APEXII diffractometer with $\mathrm{Cu} \mathrm{K}_{\alpha}(\lambda=$ $1.54178 \AA$ ) radiation and the diffractometer to crystal distance of $4.0 \mathrm{~cm}^{\mathrm{S} 3}$

The initial cell constants were obtained from three series of $\omega$ scans at different starting angles. Each series consisted of 41 frames collected at intervals of $0.6^{\circ}$ in a $25^{\circ}$ range about $\omega$ with the exposure time of 10 seconds per frame. The reflections were successfully indexed by an automated indexing routine built in the APEXII program. The final cell constants were calculated from a set of 9989 strong reflections from the actual data collection.

The data were collected by using the full sphere data collection routine to survey the reciprocal space to the extent of a full sphere to a resolution of $0.80 \AA$. A total of 70433 data were harvested by collecting 16 sets of frames with $0.65^{\circ}$ scans in $\omega$ and $\varphi$ with an exposure times 30-60 sec per frame. These highly redundant datasets were corrected for Lorentz and polarization effects. The absorption correction was based on fitting a function to the empirical transmission surface as sampled by multiple equivalent measurements. ${ }^{\mathrm{S} 6}$

\section{Structure Solution and Refinement}

The systematic absences in the diffraction data were uniquely consistent for the space group $P 2{ }_{1} 2_{1} 2_{1}$ that yielded chemically reasonable and computationally stable results of refinement. ${ }^{\text {S4b,S4c,S7 }}$

A successful solution by the direct methods provided most non-hydrogen atoms from the $E$-map. The remaining nonhydrogen atoms were located in an alternating series of least-squares cycles and difference Fourier maps. All non-hydrogen atoms were refined with anisotropic displacement coefficients. All non-amido hydrogen atoms were included in the structure factor calculation at idealized positions and were allowed to ride on the neighboring atoms with relative isotropic displacement coefficients.

The absolute configuration was unequivocally established by anomalous dispersion. The chiral centers are: C6 - R, C11 S, C13 - S, C18 - R, C20 - R, C25 - S, C27 - S, C32 - R, C34 - R, C39 - S.

There was a partially occupied solvent molecule of either pentane or diethyl ether (or a mixture of both) present in the asymmetric unit. The solvent molecules occupied lattice channels propagating in the [100] direction in the crystal. Due to the continuous nature of the channels, the solvent molecules were randomly disordered in the channels and it was not possible to

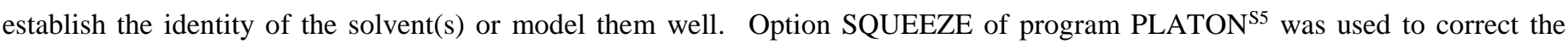
diffraction data for diffuse scattering effects and to identify the solvent molecule. PLATON calculated the upper limit of volume that can be occupied by the solvent to be $492.5 \AA^{3}$, or $11 \%$ of the unit cell volume. The program calculated 120 electrons in the unit cell for the diffuse species. This approximately corresponds to 0.72 molecules of pentane (or $\mathrm{Et}_{2} \mathrm{O}$ ) $\mathrm{molecule}$ in the asymmetric unit (168 electrons). Note that all derived results in the following tables are based on the known contents. The reported composition takes into account 0.72 molecules of (arbitrarily chosen from the reported crystallization solvents) pentane, but no other data are given for the diffusely scattering species.

The final least-squares refinement of 685 parameters against 9780 data resulted in residuals $R$ (based on $F^{2}$ for $I \geq 2 \sigma$ ) and $w R$ (based on $F^{2}$ for all data) of 0.0361 and 0.0821 , respectively. The final difference Fourier map was featureless.

\section{Summary}

Crystal Data for $\mathrm{C}_{44.5} \mathrm{H}_{76.5} \mathrm{~N}_{6} \mathrm{O}_{7}(M=807.61 \mathrm{~g} / \mathrm{mol})$ : orthorhombic, space group $\mathrm{P} 22_{1} 2_{1} 2_{1}($ no. 19$), a=9.727(2) \AA, b=$ 17.750(3) $\AA, c=25.980(3) \AA, V=4485.6(14) \AA^{3}, Z=4, T=100.0 \mathrm{~K}, \mu(\mathrm{CuK} \alpha)=0.644 \mathrm{~mm}^{-1}$, Dcalc $=1.196 \mathrm{~g} / \mathrm{cm}^{3}, 70433$ reflections measured $\left(6.03^{\circ} \leq 2 \Theta \leq 147.428^{\circ}\right), 8738$ unique $\left(R_{\text {int }}=0.0755, \mathrm{R}_{\text {sigma }}=0.0395\right)$ which were used in all calculations. The final $R_{1}$ was $0.0361(\mathrm{I}>2 \sigma(\mathrm{I}))$ and $w R_{2}$ was 0.0821 (all data). 


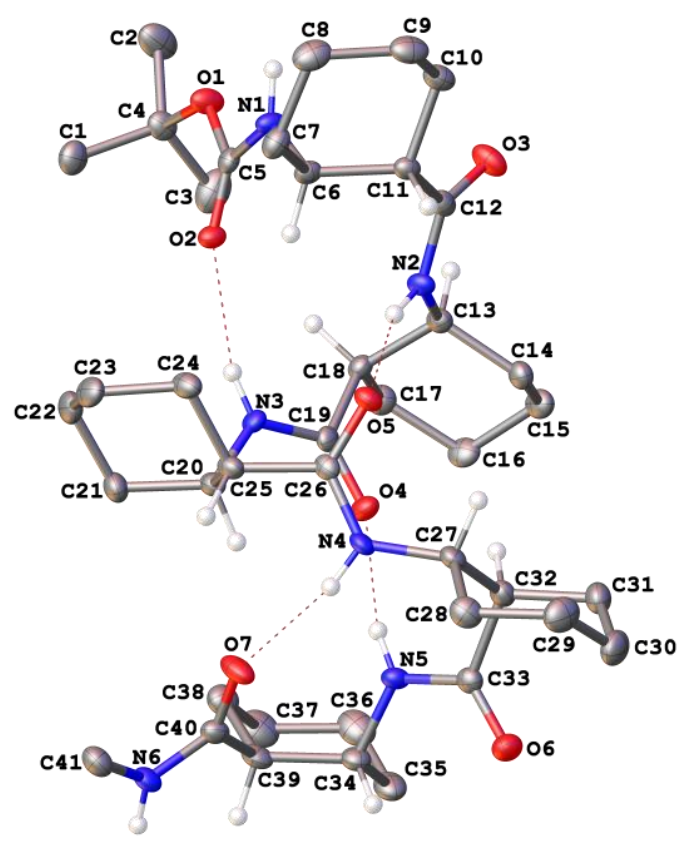

Figure S12. A molecular drawing of $\mathbf{2}$ shown with 50\% probability ellipsoids. Selected $\mathrm{H}$ atoms are shown.

Table S7. Crystal data and structure refinement for 2.

\begin{tabular}{|c|c|}
\hline Empirical formula & $\mathrm{C}_{41} \mathrm{H}_{68} \mathrm{~N}_{6} \mathrm{O}_{7} .0 .72$ pentane \\
\hline Formula weight & 807.61 \\
\hline Temperature/K & 100.0 \\
\hline Crystal system & orthorhombic \\
\hline Space group & $\mathrm{P} 2{ }_{1} 2_{1} 2_{1}$ \\
\hline $\mathrm{a} / \AA$ & $9.727(2)$ \\
\hline $\mathrm{b} / \AA$ & $17.750(3)$ \\
\hline$c / \AA$ & $25.980(3)$ \\
\hline$\alpha /{ }^{\circ}$ & 90 \\
\hline$\beta /{ }^{\circ}$ & 90 \\
\hline$\gamma /{ }^{\circ}$ & 90 \\
\hline Volume $/ \AA^{3}$ & $4485.6(14)$ \\
\hline $\mathrm{Z}$ & 4 \\
\hline$\rho_{\text {calc }} \mathrm{g} / \mathrm{cm}^{3}$ & 1.196 \\
\hline$\mu / \mathrm{mm}^{-1}$ & 0.644 \\
\hline $\mathrm{F}(000)$ & 1766.0 \\
\hline Crystal size $/ \mathrm{mm}^{3}$ & $0.254 \times 0.104 \times 0.054$ \\
\hline Radiation & $\mathrm{CuK} \alpha(\lambda=1.54178)$ \\
\hline \multicolumn{2}{|c|}{$2 \Theta$ range for data collection $/{ }^{\circ} 6.03$ to 147.428} \\
\hline Index ranges & $-11 \leq \mathrm{h} \leq 9,-22 \leq \mathrm{k} \leq 21,-32 \leq 1 \leq 31$ \\
\hline Reflections collected & 70433 \\
\hline Independent reflections & $8738\left[\mathrm{R}_{\text {int }}=0.0755, \mathrm{R}_{\text {sigma }}=0.0395\right]$ \\
\hline Data/restraints/parameters & $8738 / 6 / 510$ \\
\hline Goodness-of-fit on $\mathrm{F}^{2}$ & 1.030 \\
\hline Final $R$ indexes $[I>=2 \sigma(I)]$ & $\mathrm{R}_{1}=0.0361, \mathrm{wR}_{2}=0.0782$ \\
\hline Final R indexes [all data] & $\mathrm{R}_{1}=0.0458, \mathrm{wR}_{2}=0.0821$ \\
\hline \multicolumn{2}{|c|}{ Largest diff. peak/hole / e $\AA^{-3} 0.19 /-0.17$} \\
\hline Flack parameter & $-0.08(9)$ \\
\hline
\end{tabular}




\section{- Pentamer 4}

\section{Data Collection}

A colorless crystal with approximate dimensions $0.22 \times 0.14 \times 0.07 \mathrm{~mm}^{3}$ was selected under oil under ambient conditions and attached to the tip of a MiTeGen MicroMount $\odot$. The crystal was mounted in a stream of cold nitrogen at 100(1) K and centered in the X-ray beam by using a video camera.

The crystal evaluation and data collection were performed on a Bruker Photon $\mathrm{I} \mu \mathrm{S}$ diffractometer with $\mathrm{Cu} \mathrm{K}_{\alpha} \quad(\lambda=$ $1.54178 \AA$ ) radiation and the diffractometer to crystal distance of $3.5 .^{\mathrm{S} 3}$

The initial cell constants were obtained from one series of $0.7^{\circ} 2$ second $\omega$ scans covering a $180^{\circ}$ range. The reflections were successfully indexed by an automated indexing routine built in the APEXII program. The final cell constants were calculated from a set of 9510 strong reflections from the actual data collection.

The data were collected by using the full sphere data collection routine to survey the reciprocal space to the extent of a

full sphere to a resolution of $0.80 \AA$ A. A total of 179483 data were harvested by collecting 35 sets of frames with $0.6^{\circ}$ scans in $\omega$ and $\varphi$ with an exposure time $6 / 11 \mathrm{sec}$ per frame. These redundant datasets were corrected for Lorentz and polarization effects. The absorption correction was based on fitting a function to the empirical transmission surface as sampled by multiple equivalent measurements. ${ }^{\mathrm{s} 6}$

\section{Structure Solution and Refinement}

The systematic absences in the diffraction data and the $E$-statistics were uniquely consistent for the space groups $P 2_{1}$ that yielded chemically reasonable and computationally stable results of refinement. ${ }^{\mathrm{S4b}, \mathrm{S4c}, \mathrm{S7}}$

A successful solution by the direct methods provided most non-hydrogen atoms from the $E$-map. The remaining nonhydrogen atoms were located in an alternating series of least-squares cycles and difference Fourier maps. All non-hydrogen atoms were refined with anisotropic displacement coefficients. All non-amido hydrogen atoms were included in the structure factor calculation at idealized positions and were allowed to ride on the neighboring atoms with relative isotropic displacement coefficients. The amido hydrogen atoms were refined independently.

The asymmetric unit contains two symmetry-independent molecules with identical compositions and chiral center configurations and very similar conformations.

The absolute configuration was unambiguously established by anomalous dispersion. The 13 chiral centers have the following configuration: $\mathrm{C} 6, \mathrm{C} 8, \mathrm{C} 19, \mathrm{C} 21, \mathrm{C} 23, \mathrm{C} 34, \mathrm{C} 36, \mathrm{C} 38-R$; $\mathrm{C} 12, \mathrm{C} 14, \mathrm{C} 27, \mathrm{C} 29, \mathrm{C} 42-S$. The assignment is consistent with the synthetic procedure.

The final least-squares refinement of 1089 parameters against 18654 data resulted in residuals $R$ (based on $F^{2}$ for $I \geq 2 \sigma$ ) and $w R$ (based on $F^{2}$ for all data) of 0.0325 and 0.0816 , espectively. The final difference Fourier map was featureless.

\section{Summary}

Crystal Data for $\mathrm{C}_{44} \mathrm{H}_{74} \mathrm{~N}_{6} \mathrm{O}_{7}(M=799.09 \mathrm{~g} / \mathrm{mol})$ : monoclinic, space group $\mathrm{P} 2_{1}$ (no. 4), $a=11.5874(16) \AA, b=23.587(3) \AA, c=$ 16.789(3) $\AA, \beta=93.663(10)^{\circ}, V=4579.1(11) \AA^{3}, Z=4, T=100.0 \mathrm{~K}, \mu(\mathrm{CuK} \alpha)=0.626 \mathrm{~mm}^{-1}$, Dcalc $=1.159 \mathrm{~g} / \mathrm{cm}^{3}, 179483$ reflections measured $\left(5.274^{\circ} \leq 2 \Theta \leq 149.52^{\circ}\right), 18654$ unique $\left(R_{\text {int }}=0.0360, \mathrm{R}_{\text {sigma }}=0.0164\right)$ which were used in all calculations. The final $R_{1}$ was 0.0325 (I $\left.>2 \sigma(\mathrm{I})\right)$ and $w R_{2}$ was 0.0816 (all data). 


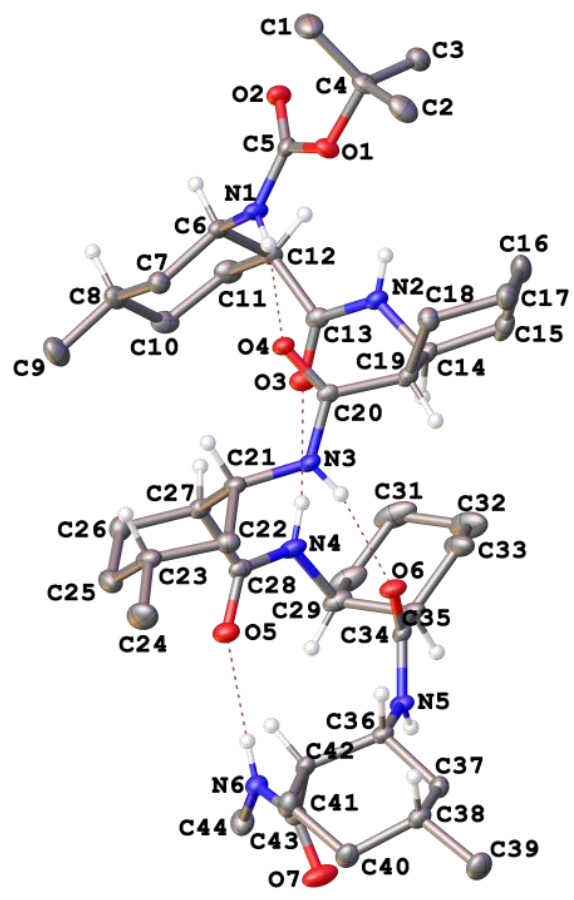

Figure S13. A molecular drawing of the first symmetry-independent molecules of 4 shown with $50 \%$ probability ellipsoids. Among the $\mathrm{H}$ atoms, only the amido $\mathrm{H}$ atoms and $\mathrm{H}$ atoms on the chiral atoms are shown.

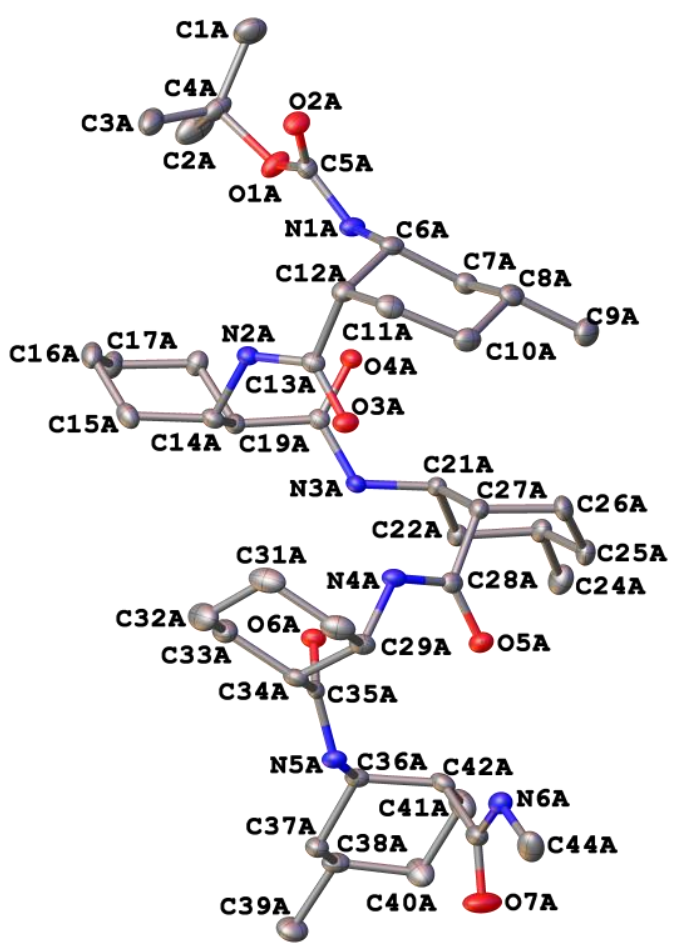

Figure S14. A molecular drawing of the second symmetry-independent molecules of 4 shown with $50 \%$ probability ellipsoids. All $\mathrm{H}$ atoms are omitted. 


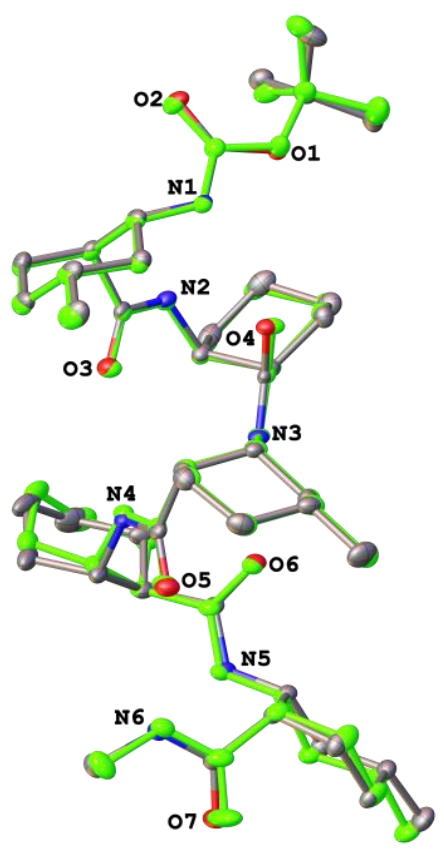

Figure S15. The two molecules superimposed. The second symmetry-independent molecule is green. All $\mathrm{H}$ atoms are omitted. The rms of the aligned non-H atoms is $0.198 \AA$.

Table S8. Crystal data and structure refinement for 4.

\begin{tabular}{|c|c|}
\hline Empirical formula & $\mathrm{C}_{44} \mathrm{H}_{74} \mathrm{~N}_{6} \mathrm{O}_{7}$ \\
\hline Formula weight & 799.09 \\
\hline Temperature/K & 100.0 \\
\hline Crystal system & monoclinic \\
\hline Space group & $\mathrm{P} 2_{1}$ \\
\hline $\mathrm{a} / \AA$ & $11.5874(16)$ \\
\hline $\mathrm{b} / \AA$ & $23.587(3)$ \\
\hline$c / \AA$ & $16.789(3)$ \\
\hline$\alpha /^{\circ}$ & 90 \\
\hline$\beta /{ }^{\circ}$ & $93.663(10)$ \\
\hline$\gamma /{ }^{\circ}$ & 90 \\
\hline Volume $/ \AA^{3}$ & 4579.1(11) \\
\hline $\mathrm{Z}$ & 4 \\
\hline$\rho_{\text {calc }} \mathrm{g} / \mathrm{cm}^{3}$ & 1.159 \\
\hline$\mu / \mathrm{mm}^{-1}$ & 0.626 \\
\hline $\mathrm{F}(000)$ & 1744.0 \\
\hline Crystal size $/ \mathrm{mm}^{3}$ & $0.22 \times 0.14 \times 0.07$ \\
\hline Radiation & $\operatorname{CuK} \alpha(\lambda=1.54178)$ \\
\hline \multicolumn{2}{|c|}{$2 \Theta$ range for data collection $/{ }^{\circ} 5.274$ to 149.52} \\
\hline Index ranges & $-14 \leq \mathrm{h} \leq 14,-29 \leq \mathrm{k} \leq 29,-19 \leq 1 \leq 21$ \\
\hline Reflections collected & 179483 \\
\hline Independent reflections & $18654\left[\mathrm{R}_{\mathrm{int}}=0.0360, \mathrm{R}_{\text {sigma }}=0.0164\right]$ \\
\hline Data/restraints/parameters & $18654 / 1 / 1089$ \\
\hline Goodness-of-fit on $\mathrm{F}^{2}$ & 1.051 \\
\hline Final $R$ indexes $[\mathrm{I}>=2 \sigma(\mathrm{I})]$ & $\mathrm{R}_{1}=0.0325, \mathrm{wR}_{2}=0.0808$ \\
\hline Final $\mathrm{R}$ indexes [all data] & $\mathrm{R}_{1}=0.0335, \mathrm{wR}_{2}=0.0816$ \\
\hline \multicolumn{2}{|c|}{ Largest diff. peak/hole / e $\AA^{-3} 0.19 /-0.18$} \\
\hline Flack parameter & $0.02(4)$ \\
\hline
\end{tabular}




\section{Copies of high-resolution mass spectra}
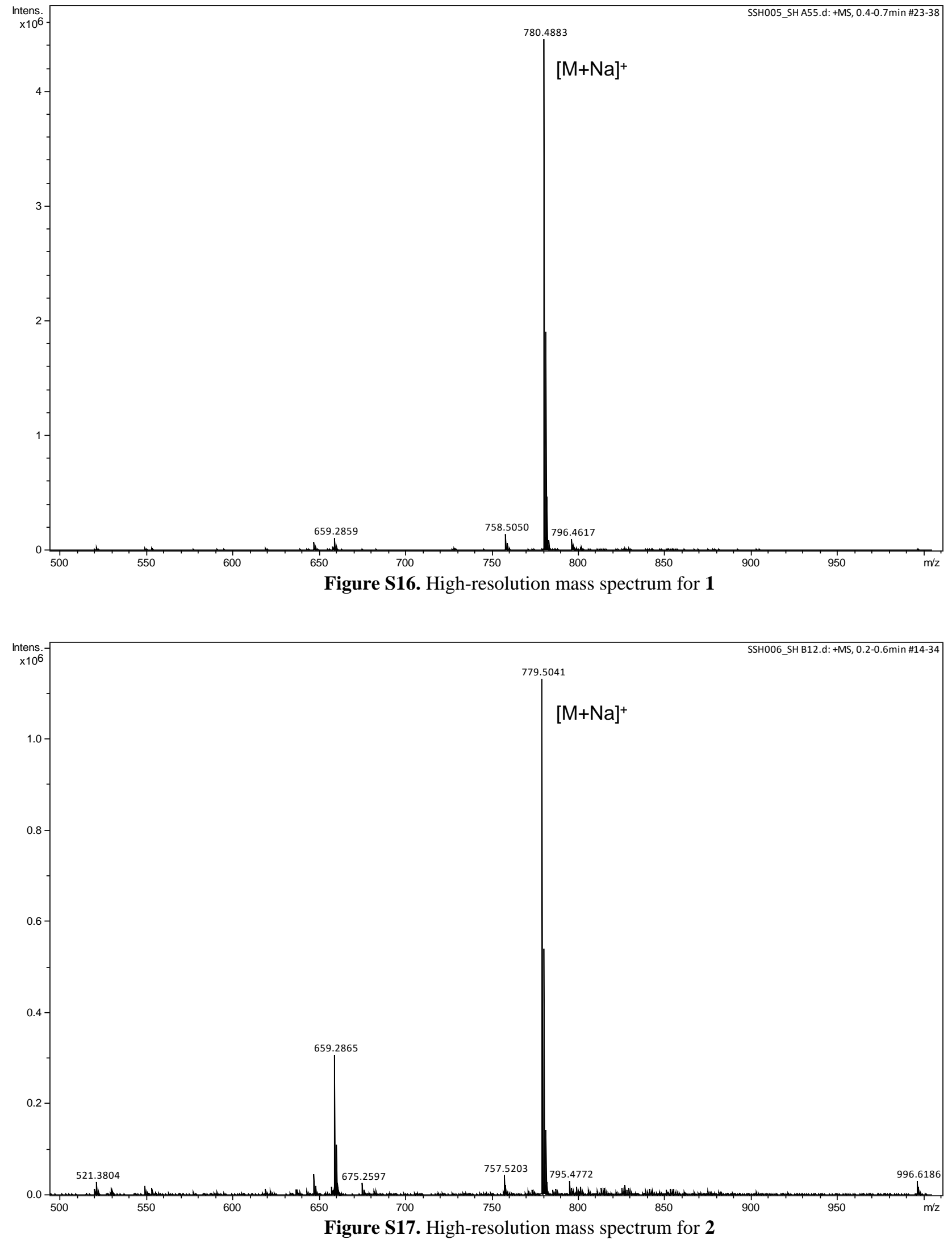


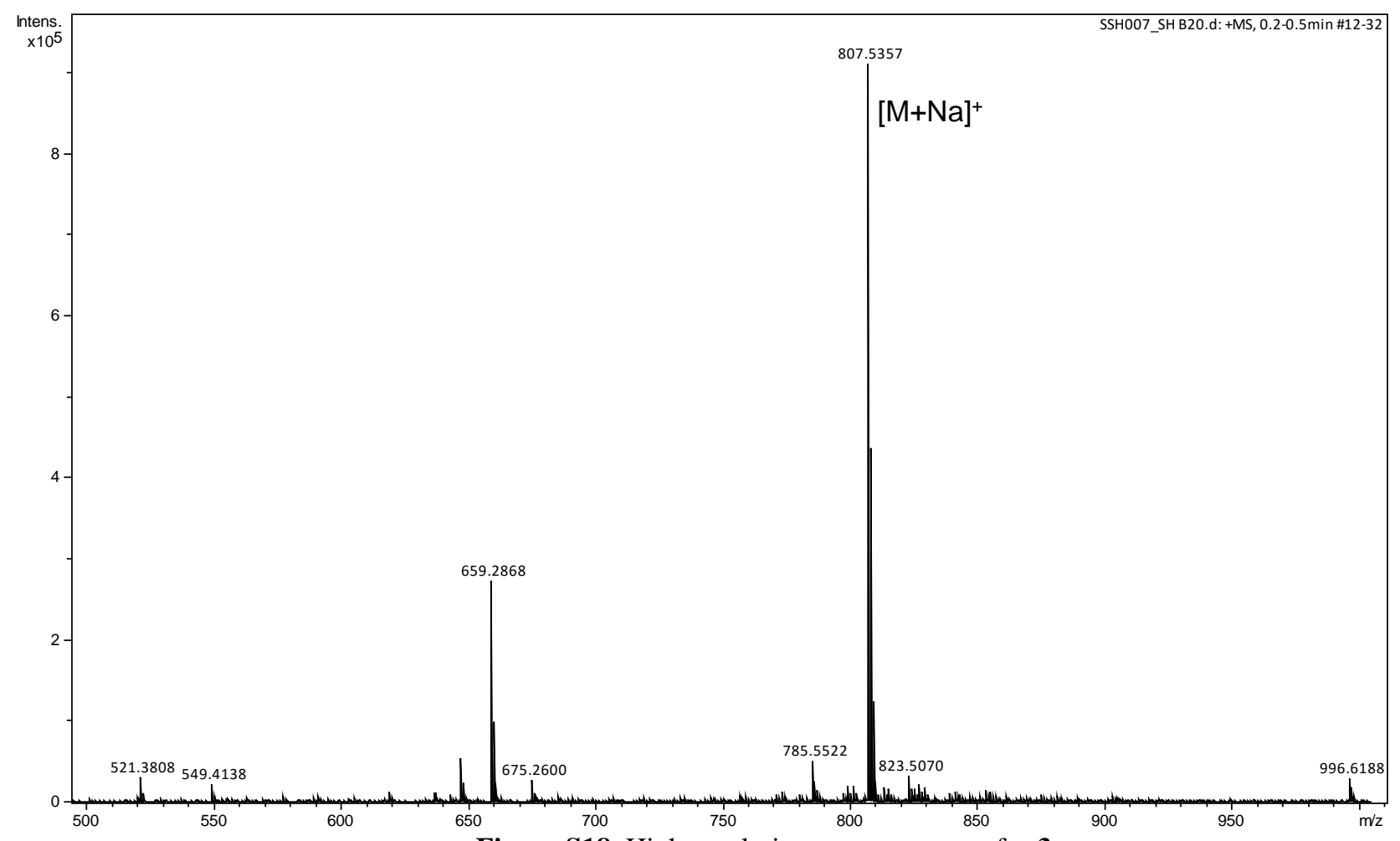

Figure S18. High-resolution mass spectrum for $\mathbf{3}$

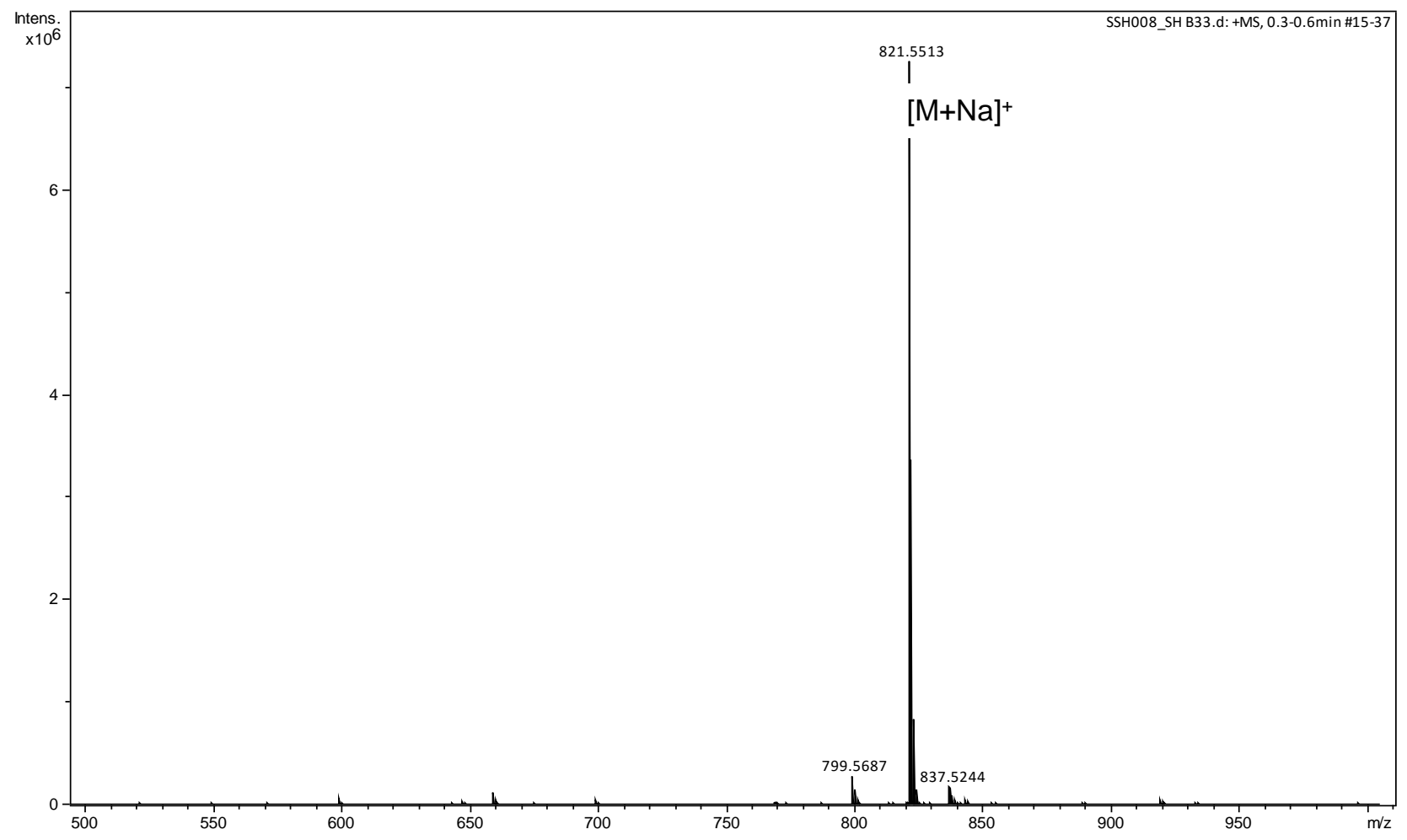

Figure S19. High-resolution mass spectrum for 4 


\section{DFT calculation}

\section{Conformational Analysis of Three Helical Foldamers}

Conformational analysis of three helical foldamers has been carried out to estimate their populations in the gas phase and in solution. All DFT calculations have been carried out using the hybrid-meta-GGA M06-2X functional $^{\mathrm{S} 8}$ implemented in the Gaussian 09 program. $^{\mathrm{S} 9}$ X-ray structures of pentamers 2 and 4 adopted leftand right-handed helices, respectively, were used as initial structures for optimization of $M-12 / 10$ and $P$ 12/10 helical foldamers, respectively. In addition, the $M-18 / 20$ helical structure of cis-2-aminocyclohex-3ene carboxylic acid optimized at the B3LYP/6-311G(d,p) level of theory ${ }^{\mathrm{S} 10}$ was used as starting point for optimization of the $M-18 / 20$ helical foldamer of pentamer 2 . Three initial structures were optimized at the M06-2X/6-31G(d) level of theory in the gas phase. For all three local minima at the M06-2X/6-31G(d) level of theory, the single-point energies $(E)$ were calculated at the M06-2X/cc-pVTZ level of theory and the solvation free energies $\left(\Delta G_{\mathrm{s}}\right)$ were calculated using the PCM method ${ }^{\mathrm{S} 11}$ in chloroform, acetonitrile, and methanol. Each relative free energy was calculated as the sum of $\Delta E$ and $\Delta \Delta G_{\mathrm{s}}$ in solution, which was used to estimate the population at $25^{\circ} \mathrm{C}$. The structures of three helical foldamers optimized at the M06-2X/631 G(d) level of theory are shown in Figure S20. Tables S9 and S10 list the absolute energies and relative free energies with corresponding populations in solution.

(a)

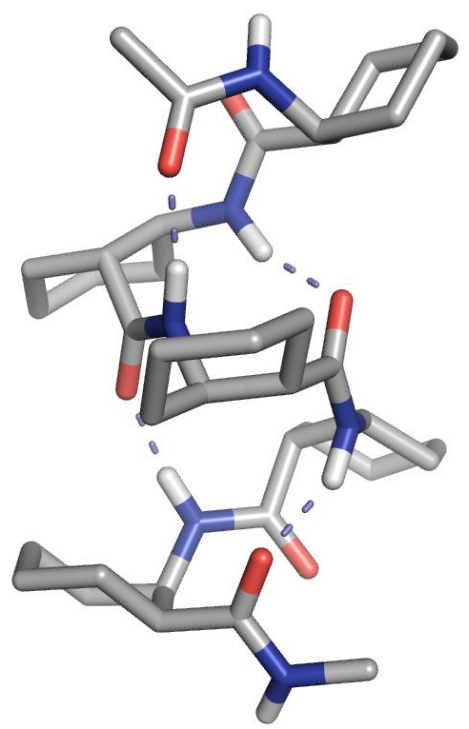

(b)

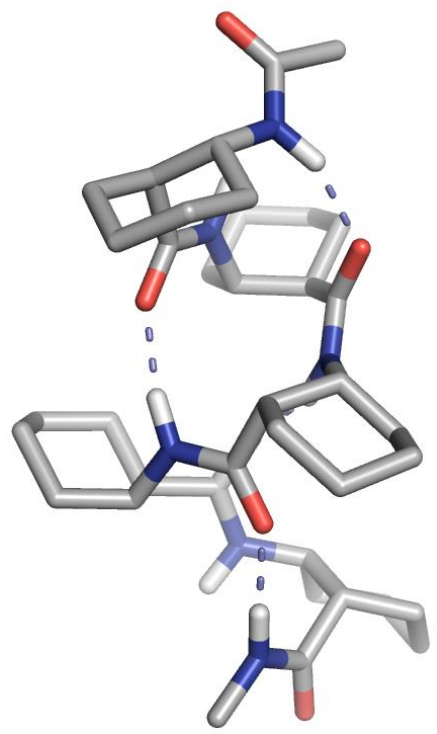

(c)

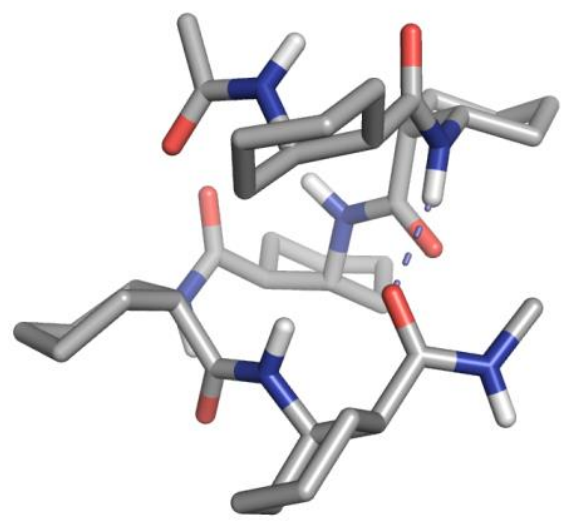

Figure S20. Optimized structures of the three helices: (a) $M$-12/10-helix; (b) $P-12 / 10$-helix; (c) $M$-18/20helix. 
Table S9. Absolute energies (hartrees) of three helical foldamers

\begin{tabular}{|c|c|c|c|c|c|}
\hline \multirow{2}{*}{ helix type } & \multicolumn{4}{|c|}{$(\mathrm{PCM}) \mathrm{M06}-2 \mathrm{X} / 6-31 \mathrm{G}(\mathrm{d})^{a}$} & M06-2X/cc-pVTZ \\
\cline { 2 - 6 } & gas phase & $\mathrm{CHCl}_{3}$ & $\mathrm{CH}_{3} \mathrm{CN}$ & $\mathrm{CH}_{3} \mathrm{OH}$ & gas phase \\
\hline$M-12 / 10$ & -2264.519975 & -2264.530113 & -2264.534457 & -2264.534383 & -2265.362756 \\
\hline$P-12 / 10$ & -2264.515233 & -2264.527574 & -2264.532740 & -2264.532653 & -2265.359209 \\
\hline$M-18 / 20$ & -2264.494915 & -2264.509636 & -2264.516199 & -2264.516085 & -2265.341265 \\
\hline
\end{tabular}

$a$. The electronic energies in solution were calculated using the PCM method.

Table S10. Relative energies, relative free energies (kcal mol-1), and populations of three helical foldamers

\begin{tabular}{|c|c|c|c|c|c|c|c|c|c|c|c|}
\hline \multirow{2}{*}{$\begin{array}{c}\text { helix } \\
\text { type }\end{array}$} & \multicolumn{2}{|c|}{ gas phase } & \multicolumn{3}{|c|}{$\mathrm{CHCl}_{3}$} & \multicolumn{3}{c|}{$\mathrm{CH}_{3} \mathrm{CN}$} & \multicolumn{3}{c|}{$\mathrm{CH}_{3} \mathrm{OH}$} \\
\cline { 2 - 13 } & $\Delta E^{\mathrm{a}}$ & $\omega(\%)^{\mathrm{b}}$ & $\Delta \Delta \mathrm{G}_{\mathrm{s}}{ }^{\mathrm{c}}$ & $\Delta \mathrm{G}^{\mathrm{d}}$ & $\omega(\%)^{\mathrm{b}}$ & $\Delta \Delta \mathrm{G}_{\mathrm{s}}^{\mathrm{c}}$ & $\Delta \mathrm{G}^{\mathrm{d}}$ & $\omega(\%)^{\mathrm{b}}$ & $\Delta \Delta \mathrm{G}_{\mathrm{s}}^{\mathrm{c}}$ & $\Delta \mathrm{G}^{\mathrm{d}}$ & $\omega(\%)^{\mathrm{b}}$ \\
\hline$M-12 / 10$ & 0.00 & 97.7 & 0.00 & 0.00 & 80.6 & 0.00 & 0.00 & 63.5 & 0.00 & 0.00 & 63.8 \\
\hline$P-12 / 10$ & 2.23 & 2.3 & -1.38 & 0.84 & 19.4 & -1.90 & 0.33 & 36.5 & -1.89 & 0.34 & 36.2 \\
\hline$M-18 / 20$ & 13.49 & 0.0 & -2.88 & 10.61 & 0.0 & -4.27 & 9.22 & 0.0 & -4.24 & 9.24 & 0.0 \\
\hline
\end{tabular}

$a$. Relative electronic energy calculated at the M06-2X/cc-pVTZ//M06-2X/6-31G(d) level of theory in the gas phase.

$b$. Populations were calculated using $\Delta E$ and $\Delta \mathrm{G}$ values in the gas phase and in solution at $25^{\circ} \mathrm{C}$, respectively.

$c$. Relative solvation free energies calculated at the M06-2X/6-31G(d) level of theory using the PCM method in solution.

$d$. Relative free energies calculated by the sum of $\Delta E$ and $\Delta \Delta$ Gs values in solution. 


\section{Cartesian Coordinates of Three Helical Foldamers Optimized at the M06-2X/6-31G(d) Level of Theory}

(1) $M-12 / 10$ Helix

\begin{tabular}{|c|c|c|c|}
\hline $\mathrm{O}$ & -3.321105 & -1.790411 & 1.580984 \\
\hline $\mathrm{O}$ & -4.545470 & -0.649628 & -2.151388 \\
\hline $\mathrm{O}$ & 1.013456 & -1.820597 & -0.687562 \\
\hline $\mathrm{O}$ & -1.267005 & 1.654975 & 0.509681 \\
\hline $\mathrm{O}$ & 4.000712 & 2.005222 & -0.865793 \\
\hline $\mathrm{O}$ & 3.184747 & 0.688292 & 2.051815 \\
\hline $\mathrm{N}$ & -4.995210 & -0.436339 & 0.834231 \\
\hline $\mathrm{H}$ & -5.842069 & -0.458696 & 0.278150 \\
\hline $\mathrm{N}$ & -2.391608 & -0.299279 & -1.493865 \\
\hline $\mathrm{H}$ & -1.784193 & 0.295521 & -0.930519 \\
\hline $\mathrm{N}$ & -0.528188 & -1.288911 & 0.895814 \\
\hline $\mathrm{H}$ & -1.506565 & -1.377349 & 1.176228 \\
\hline $\mathrm{N}$ & 0.960803 & 2.101879 & 0.607646 \\
\hline $\mathrm{H}$ & 1.827598 & 1.876592 & 1.098066 \\
\hline $\mathrm{N}$ & 3.394903 & -0.178688 & -0.935429 \\
\hline $\mathrm{H}$ & 2.607078 & -0.827029 & -0.948486 \\
\hline $\mathrm{N}$ & 5.304804 & 1.439481 & 1.841588 \\
\hline $\mathrm{H}$ & 6.158793 & 1.305376 & 1.317756 \\
\hline $\mathrm{C}$ & -4.444814 & -1.646302 & 1.099500 \\
\hline $\mathrm{C}$ & -4.182297 & 0.775588 & 0.742311 \\
\hline $\mathrm{H}$ & -3.177377 & 0.491937 & 1.049398 \\
\hline $\mathrm{C}$ & -4.689089 & 1.890965 & 1.653999 \\
\hline $\mathrm{H}$ & -3.920497 & 2.675429 & 1.666570 \\
\hline $\mathrm{H}$ & -4.780053 & 1.502585 & 2.674370 \\
\hline C & -6.015615 & 2.473867 & 1.163247 \\
\hline $\mathrm{H}$ & -6.796193 & 1.700807 & 1.215196 \\
\hline $\mathrm{H}$ & -6.338595 & 3.286123 & 1.823083 \\
\hline $\mathrm{C}$ & -5.888221 & 2.972018 & -0.278672 \\
\hline $\mathrm{H}$ & -5.161448 & 3.795719 & -0.308756 \\
\hline $\mathrm{H}$ & -6.842949 & 3.378644 & -0.629353 \\
\hline $\mathrm{C}$ & -5.423074 & 1.852018 & -1.211489 \\
\hline $\mathrm{H}$ & -5.300347 & 2.222030 & -2.234946 \\
\hline $\mathrm{H}$ & -6.189017 & 1.068328 & -1.274390 \\
\hline $\mathrm{C}$ & -4.104828 & 1.241923 & -0.730508 \\
\hline $\mathrm{H}$ & -3.307368 & 1.993577 & -0.771893 \\
\hline $\mathrm{C}$ & -3.709968 & 0.023980 & -1.557201 \\
\hline $\mathrm{C}$ & -1.873159 & -1.503130 & -2.117315 \\
\hline $\mathrm{H}$ & -2.751418 & -1.996582 & -2.548798 \\
\hline $\mathrm{C}$ & -0.896222 & -1.205673 & -3.257123 \\
\hline $\mathrm{H}$ & 0.010529 & -0.730353 & -2.859786 \\
\hline $\mathrm{H}$ & -1.369231 & -0.496843 & -3.945348 \\
\hline C & -0.522639 & -2.502805 & -3.977844 \\
\hline $\mathrm{H}$ & -1.431345 & -2.934171 & -4.421590 \\
\hline $\mathrm{H}$ & 0.164341 & -2.293615 & -4.804940 \\
\hline $\mathrm{C}$ & 0.103971 & -3.508165 & -3.010374 \\
\hline $\mathrm{H}$ & 1.067717 & -3.125364 & -2.665057 \\
\hline $\mathrm{H}$ & 0.290307 & -4.458312 & -3.524120 \\
\hline $\mathrm{C}$ & -0.799319 & -3.764681 & -1.798025 \\
\hline $\mathrm{H}$ & -0.291615 & -4.419086 & -1.080774 \\
\hline $\mathrm{H}$ & -1.698811 & -4.298947 & -2.133221 \\
\hline $\mathrm{C}$ & -1.275535 & -2.486707 & -1.082531 \\
\hline $\mathrm{H}$ & -2.079331 & -2.743056 & -0.382271 \\
\hline $\mathrm{C}$ & -0.155797 & -1.840632 & -0.274894 \\
\hline$C$ & 0.437838 & -0.710321 & 1.823725 \\
\hline
\end{tabular}




\begin{tabular}{|c|c|c|c|}
\hline $\mathrm{H}$ & 1.363008 & -0.582853 & 1.261738 \\
\hline $\mathrm{C}$ & 0.682252 & -1.631774 & 3.022703 \\
\hline $\mathrm{H}$ & 0.960793 & -2.627075 & 2.656092 \\
\hline $\mathrm{H}$ & 1.543508 & -1.231429 & 3.574681 \\
\hline $\mathrm{C}$ & -0.544414 & -1.705640 & 3.936354 \\
\hline $\mathrm{H}$ & -0.331350 & -2.351543 & 4.795103 \\
\hline $\mathrm{H}$ & -1.382268 & -2.164057 & 3.393319 \\
\hline $\mathrm{C}$ & -0.961496 & -0.309831 & 4.409378 \\
\hline $\mathrm{H}$ & -1.853517 & -0.375373 & 5.041264 \\
\hline $\mathrm{H}$ & -0.160982 & 0.120377 & 5.027947 \\
\hline $\mathrm{C}$ & -1.236518 & 0.609225 & 3.215220 \\
\hline $\mathrm{H}$ & -1.521650 & 1.614009 & 3.547170 \\
\hline $\mathrm{H}$ & -2.086287 & 0.206986 & 2.652083 \\
\hline $\mathrm{C}$ & -0.001303 & 0.688425 & 2.317739 \\
\hline $\mathrm{H}$ & 0.847666 & 1.070909 & 2.898962 \\
\hline $\mathrm{C}$ & -0.177908 & 1.548547 & 1.082945 \\
\hline $\mathrm{C}$ & 1.058228 & 2.564299 & -0.769419 \\
\hline $\mathrm{H}$ & 0.025178 & 2.627401 & -1.129004 \\
\hline $\mathrm{C}$ & 1.687501 & 3.951688 & -0.894367 \\
\hline $\mathrm{H}$ & 2.698199 & 3.935414 & -0.476092 \\
\hline $\mathrm{H}$ & 1.087121 & 4.658781 & -0.311447 \\
\hline $\mathrm{C}$ & 1.743057 & 4.371538 & -2.366977 \\
\hline $\mathrm{H}$ & 0.717148 & 4.473539 & -2.750008 \\
\hline $\mathrm{H}$ & 2.212611 & 5.356710 & -2.458113 \\
\hline $\mathrm{C}$ & 2.494702 & 3.344176 & -3.217862 \\
\hline $\mathrm{H}$ & 3.538796 & 3.296136 & -2.892013 \\
\hline $\mathrm{H}$ & 2.489198 & 3.650314 & -4.270006 \\
\hline $\mathrm{C}$ & 1.857735 & 1.957571 & -3.088657 \\
\hline $\mathrm{H}$ & 2.410052 & 1.214316 & -3.675549 \\
\hline $\mathrm{H}$ & 0.836496 & 1.988345 & -3.493771 \\
\hline $\mathrm{C}$ & 1.761954 & 1.491467 & -1.623052 \\
\hline $\mathrm{H}$ & 1.146657 & 0.584263 & -1.570986 \\
\hline $\mathrm{C}$ & 3.147120 & 1.145699 & -1.090300 \\
\hline $\mathrm{C}$ & 4.703352 & -0.641467 & -0.504772 \\
\hline $\mathrm{H}$ & 5.403593 & 0.142080 & -0.810423 \\
\hline $\mathrm{C}$ & 5.075233 & -1.956292 & -1.199097 \\
\hline $\mathrm{H}$ & 4.966823 & -1.823595 & -2.280678 \\
\hline $\mathrm{H}$ & 6.136907 & -2.155591 & -0.999545 \\
\hline $\mathrm{C}$ & 4.244870 & -3.142100 & -0.701991 \\
\hline $\mathrm{H}$ & 3.186041 & -2.999501 & -0.957211 \\
\hline $\mathrm{H}$ & 4.573120 & -4.057166 & -1.206601 \\
\hline $\mathrm{C}$ & 4.375190 & -3.286295 & 0.815246 \\
\hline $\mathrm{H}$ & 5.417342 & -3.522858 & 1.074386 \\
\hline $\mathrm{H}$ & 3.760841 & -4.119583 & 1.172413 \\
\hline $\mathrm{C}$ & 3.946372 & -1.993642 & 1.510784 \\
\hline $\mathrm{H}$ & 4.013861 & -2.086204 & 2.600492 \\
\hline $\mathrm{H}$ & 2.895621 & -1.799593 & 1.271918 \\
\hline $\mathrm{C}$ & 4.785213 & -0.804341 & 1.039116 \\
\hline $\mathrm{H}$ & 5.841649 & -0.986818 & 1.285666 \\
\hline $\mathrm{C}$ & 4.347127 & 0.495063 & 1.694161 \\
\hline $\mathrm{C}$ & 4.920723 & 2.805938 & 2.145649 \\
\hline $\mathrm{H}$ & 4.408380 & 3.260076 & 1.289870 \\
\hline $\mathrm{H}$ & 5.813494 & 3.382098 & 2.392118 \\
\hline $\mathrm{H}$ & 4.249204 & 2.798800 & 3.004935 \\
\hline $\mathrm{C}$ & -5.302892 & -2.834992 & 0.728886 \\
\hline $\mathrm{H}$ & -4.948402 & -3.715995 & 1.262827 \\
\hline $\mathrm{H}$ & -6.359038 & -2.662758 & 0.951583 \\
\hline $\mathrm{H}$ & -5.202930 & -2.996894 & -0.350446 \\
\hline
\end{tabular}




\section{(2) $P-12 / 10$ Helix}

\begin{tabular}{|c|c|c|c|}
\hline $\mathrm{O}$ & 7.007347 & 0.877540 & -0.152118 \\
\hline $\mathrm{O}$ & 2.028197 & -0.990761 & 1.483989 \\
\hline $\mathrm{O}$ & 2.411911 & 1.061159 & -2.234016 \\
\hline $\mathrm{O}$ & -2.211015 & -1.784726 & -0.740138 \\
\hline $\mathrm{O}$ & -1.376507 & 1.241301 & 0.769929 \\
\hline $\mathrm{O}$ & -6.733168 & -0.053393 & -0.179049 \\
\hline $\mathrm{N}$ & 4.977803 & 0.451515 & -1.066391 \\
\hline $\mathrm{H}$ & 4.215595 & 0.767391 & -1.666383 \\
\hline $\mathrm{N}$ & 2.929280 & 1.010405 & 0.915425 \\
\hline $\mathrm{H}$ & 3.771609 & 1.454515 & 0.572591 \\
\hline $\mathrm{N}$ & 0.330921 & 0.500957 & -1.511305 \\
\hline $\mathrm{H}$ & -0.415024 & 0.733592 & -0.854149 \\
\hline $\mathrm{N}$ & -0.733246 & -1.740028 & 0.985150 \\
\hline $\mathrm{H}$ & 0.244311 & -1.586769 & 1.233940 \\
\hline $\mathrm{N}$ & -3.569295 & 0.930126 & 1.250960 \\
\hline $\mathrm{H}$ & -4.232124 & 0.401453 & 1.804850 \\
\hline $\mathrm{N}$ & -5.023038 & -1.524356 & -0.098494 \\
\hline $\mathrm{H}$ & -4.057154 & -1.723297 & -0.349216 \\
\hline $\mathrm{C}$ & 6.086052 & 1.219969 & -0.877775 \\
\hline $\mathrm{C}$ & 4.894483 & -0.885460 & -0.506203 \\
\hline $\mathrm{H}$ & 5.922172 & -1.268925 & -0.476725 \\
\hline $\mathrm{C}$ & 4.044626 & -1.791974 & -1.393808 \\
\hline $\mathrm{H}$ & 4.402415 & -1.720262 & -2.426942 \\
\hline $\mathrm{H}$ & 3.007990 & -1.424462 & -1.393382 \\
\hline C & 4.111276 & -3.237011 & -0.893691 \\
\hline $\mathrm{H}$ & 5.144721 & -3.595023 & -1.000585 \\
\hline C & 3.680041 & -3.351377 & 0.569913 \\
\hline $\mathrm{H}$ & 3.842219 & -4.375066 & 0.925648 \\
\hline $\mathrm{H}$ & 2.607856 & -3.148548 & 0.655011 \\
\hline $\mathrm{C}$ & 4.444016 & -2.374278 & 1.471876 \\
\hline $\mathrm{H}$ & 5.498914 & -2.674476 & 1.518233 \\
\hline $\mathrm{H}$ & 4.048928 & -2.420431 & 2.491207 \\
\hline $\mathrm{C}$ & 4.398077 & -0.926085 & 0.965619 \\
\hline $\mathrm{H}$ & 5.099416 & -0.311385 & 1.544893 \\
\hline C & 3.006290 & -0.319028 & 1.139345 \\
\hline $\mathrm{C}$ & 1.683761 & 1.766941 & 0.916226 \\
\hline $\mathrm{H}$ & 0.889003 & 1.050006 & 1.114530 \\
\hline $\mathrm{C}$ & 1.686149 & 2.854541 & 1.993036 \\
\hline $\mathrm{H}$ & 0.672252 & 3.273534 & 2.044833 \\
\hline $\mathrm{H}$ & 1.901182 & 2.395125 & 2.964476 \\
\hline $\mathrm{C}$ & 2.692262 & 3.963771 & 1.675281 \\
\hline $\mathrm{H}$ & 3.712241 & 3.553581 & 1.708457 \\
\hline $\mathrm{H}$ & 2.649558 & 4.741479 & 2.444910 \\
\hline $\mathrm{C}$ & 2.431009 & 4.566992 & 0.291953 \\
\hline $\mathrm{H}$ & 3.179960 & 5.332990 & 0.063661 \\
\hline $\mathrm{H}$ & 1.454151 & 5.070144 & 0.299358 \\
\hline $\mathrm{C}$ & 2.432441 & 3.489670 & -0.794986 \\
\hline $\mathrm{H}$ & 3.431917 & 3.042815 & -0.881194 \\
\hline $\mathrm{H}$ & 2.215376 & 3.920936 & -1.777877 \\
\hline $\mathrm{C}$ & 1.421804 & 2.390153 & -0.474827 \\
\hline $\mathrm{H}$ & 0.410400 & 2.815870 & -0.429898 \\
\hline $\mathrm{C}$ & 1.438090 & 1.272398 & -1.506608 \\
\hline $\mathrm{C}$ & 0.249611 & -0.748026 & -2.248881 \\
\hline $\mathrm{H}$ & 1.212729 & -0.847808 & -2.763257 \\
\hline $\mathrm{C}$ & -0.851538 & -0.735880 & -3.310947 \\
\hline $\mathrm{H}$ & -0.670077 & 0.108014 & -3.985306 \\
\hline
\end{tabular}




\begin{tabular}{|c|c|c|c|}
\hline $\mathrm{H}$ & -1.824615 & -0.581800 & -2.831716 \\
\hline C & -0.853480 & -2.057812 & -4.083582 \\
\hline $\mathrm{H}$ & 0.097596 & -2.154365 & -4.626923 \\
\hline C & -1.021993 & -3.254068 & -3.144304 \\
\hline $\mathrm{H}$ & -0.968564 & -4.189773 & -3.711871 \\
\hline $\mathrm{H}$ & -2.007711 & -3.209271 & -2.671860 \\
\hline $\mathrm{C}$ & 0.060683 & -3.258925 & -2.060818 \\
\hline $\mathrm{H}$ & 1.041313 & -3.407341 & -2.535009 \\
\hline $\mathrm{H}$ & -0.084010 & -4.094267 & -1.365891 \\
\hline $\mathrm{C}$ & 0.137866 & -1.936872 & -1.272772 \\
\hline $\mathrm{H}$ & 1.048197 & -1.939226 & -0.662047 \\
\hline C & -1.045902 & -1.798997 & -0.325906 \\
\hline C & -1.745963 & -1.678084 & 2.027610 \\
\hline $\mathrm{H}$ & -2.684301 & -1.981757 & 1.553229 \\
\hline $\mathrm{C}$ & -1.403288 & -2.647840 & 3.166193 \\
\hline $\mathrm{H}$ & -2.271143 & -2.705219 & 3.836719 \\
\hline $\mathrm{H}$ & -1.251277 & -3.645994 & 2.742751 \\
\hline $\mathrm{C}$ & -0.178466 & -2.196916 & 3.966503 \\
\hline $\mathrm{H}$ & 0.004474 & -2.902281 & 4.783912 \\
\hline $\mathrm{H}$ & 0.716471 & -2.212405 & 3.330026 \\
\hline $\mathrm{C}$ & -0.379792 & -0.781427 & 4.512686 \\
\hline $\mathrm{H}$ & 0.512378 & -0.454489 & 5.056624 \\
\hline $\mathrm{H}$ & -1.211669 & -0.780079 & 5.231544 \\
\hline $\mathrm{C}$ & -0.679449 & 0.195560 & 3.373569 \\
\hline $\mathrm{H}$ & -0.821614 & 1.213797 & 3.753089 \\
\hline $\mathrm{H}$ & 0.182312 & 0.218609 & 2.699117 \\
\hline C & -1.920472 & -0.242720 & 2.591216 \\
\hline $\mathrm{H}$ & -2.774421 & -0.282883 & 3.283073 \\
\hline C & -2.254805 & 0.713492 & 1.457624 \\
\hline $\mathrm{C}$ & -4.096526 & 1.662844 & 0.107314 \\
\hline $\mathrm{H}$ & -3.250567 & 2.232654 & -0.291774 \\
\hline $\mathrm{C}$ & -5.195604 & 2.632792 & 0.539284 \\
\hline $\mathrm{H}$ & -4.794643 & 3.302521 & 1.308116 \\
\hline $\mathrm{H}$ & -6.026003 & 2.067367 & 0.980698 \\
\hline C & -5.704775 & 3.425712 & -0.666634 \\
\hline $\mathrm{H}$ & -4.881338 & 4.033810 & -1.068905 \\
\hline $\mathrm{C}$ & -6.233349 & 2.491320 & -1.755752 \\
\hline $\mathrm{H}$ & -6.541375 & 3.072826 & -2.631977 \\
\hline $\mathrm{H}$ & -7.110828 & 1.957361 & -1.381736 \\
\hline C & -5.168209 & 1.472885 & -2.175071 \\
\hline $\mathrm{H}$ & -4.342028 & 2.001058 & -2.671381 \\
\hline $\mathrm{H}$ & -5.579488 & 0.770625 & -2.908163 \\
\hline C & -4.570051 & 0.688007 & -0.995232 \\
\hline $\mathrm{H}$ & -3.683918 & 0.136387 & -1.333077 \\
\hline $\mathrm{C}$ & -5.556798 & -0.318709 & -0.408875 \\
\hline $\mathrm{C}$ & -5.868037 & -2.574312 & 0.431652 \\
\hline $\mathrm{H}$ & -6.422757 & -2.211092 & 1.300909 \\
\hline $\mathrm{H}$ & -5.240855 & -3.417627 & 0.725441 \\
\hline $\mathrm{H}$ & -6.599343 & -2.911698 & -0.310479 \\
\hline $\mathrm{C}$ & 6.085672 & 2.550114 & -1.608356 \\
\hline $\mathrm{H}$ & 5.277710 & 2.635258 & -2.339312 \\
\hline $\mathrm{H}$ & 5.993600 & 3.358556 & -0.875979 \\
\hline $\mathrm{H}$ & 7.049562 & 2.669612 & -2.107163 \\
\hline $\mathrm{H}$ & 3.488378 & -3.883154 & -1.522409 \\
\hline $\mathrm{H}$ & -1.648176 & -2.051278 & -4.836926 \\
\hline $\mathrm{H}$ & -6.487273 & 4.123113 & -0.349774 \\
\hline
\end{tabular}




\section{(3) $M-18 / 20$ Helix}

\begin{tabular}{|c|c|c|c|}
\hline C & 0.960612 & -2.273926 & -1.487903 \\
\hline $\mathrm{C}$ & 2.490502 & -2.315826 & -1.562731 \\
\hline $\mathrm{C}$ & 3.003634 & -3.621460 & -2.168349 \\
\hline $\mathrm{C}$ & 0.951242 & -4.823693 & -1.355145 \\
\hline $\mathrm{C}$ & 2.479327 & -4.827203 & -1.388336 \\
\hline $\mathrm{C}$ & 0.412961 & -3.520421 & -0.756419 \\
\hline $\mathrm{C}$ & -1.104510 & -3.466445 & -0.832680 \\
\hline $\mathrm{C}$ & -0.440458 & -1.004554 & -4.794087 \\
\hline $\mathrm{C}$ & 0.397027 & -1.038104 & -3.532158 \\
\hline $\mathrm{C}$ & -2.112917 & 2.455918 & 0.792041 \\
\hline $\mathrm{C}$ & -4.442343 & 3.308062 & 1.312437 \\
\hline $\mathrm{C}$ & -3.125769 & 2.791580 & 1.894898 \\
\hline $\mathrm{C}$ & -3.205473 & 4.206761 & -0.697878 \\
\hline $\mathrm{C}$ & -4.206571 & 4.524067 & 0.414056 \\
\hline $\mathrm{C}$ & -1.887309 & 3.681205 & -0.120588 \\
\hline $\mathrm{C}$ & -0.905641 & 3.281030 & -1.215738 \\
\hline $\mathrm{C}$ & -3.126288 & -2.377272 & -0.025947 \\
\hline $\mathrm{C}$ & -3.962393 & -2.691753 & 1.219049 \\
\hline $\mathrm{C}$ & -5.430706 & -2.318089 & 0.994089 \\
\hline $\mathrm{C}$ & -4.770696 & -0.600576 & -0.720411 \\
\hline $\mathrm{C}$ & -5.570895 & -0.857173 & 0.558252 \\
\hline $\mathrm{C}$ & -3.278015 & -0.926708 & -0.511693 \\
\hline $\mathrm{C}$ & -2.664917 & 0.085778 & 0.455613 \\
\hline $\mathrm{C}$ & 2.421964 & 0.779229 & 2.699397 \\
\hline $\mathrm{C}$ & 4.946553 & 0.540587 & 2.652760 \\
\hline $\mathrm{C}$ & 3.766423 & 1.382490 & 3.138044 \\
\hline $\mathrm{C}$ & 3.500969 & -1.526055 & 2.751946 \\
\hline $\mathrm{C}$ & 4.836767 & -0.899582 & 3.155301 \\
\hline $\mathrm{C}$ & 2.318141 & -0.665530 & 3.229427 \\
\hline $\mathrm{C}$ & 1.011341 & -1.337920 & 2.841887 \\
\hline $\mathrm{C}$ & 1.525100 & 3.025446 & -1.658931 \\
\hline $\mathrm{C}$ & 2.599777 & 4.108928 & -1.800839 \\
\hline $\mathrm{C}$ & 3.890922 & 3.564994 & -2.411135 \\
\hline $\mathrm{C}$ & 3.357796 & 1.268314 & -1.569368 \\
\hline $\mathrm{C}$ & 4.409038 & 2.376736 & -1.599853 \\
\hline $\mathrm{C}$ & 2.028587 & 1.750080 & -0.954543 \\
\hline $\mathrm{C}$ & 2.184356 & 1.940966 & 0.548447 \\
\hline $\mathrm{O}$ & 1.080527 & -0.078483 & -3.196125 \\
\hline $\mathrm{N}$ & 0.352160 & -2.189071 & -2.814608 \\
\hline $\mathrm{H}$ & 0.226008 & -0.954240 & -5.659022 \\
\hline $\mathrm{H}$ & -0.351498 & -2.883576 & -3.045401 \\
\hline $\mathrm{H}$ & 0.658687 & -1.381454 & -0.921458 \\
\hline $\mathrm{H}$ & 2.832330 & -1.450944 & -2.136963 \\
\hline $\mathrm{H}$ & 2.873779 & -2.209137 & -0.536663 \\
\hline $\mathrm{H}$ & 2.665209 & -3.688077 & -3.210756 \\
\hline $\mathrm{H}$ & 4.098801 & -3.619260 & -2.187779 \\
\hline $\mathrm{H}$ & 2.842498 & -5.761026 & -1.831153 \\
\hline $\mathrm{H}$ & 2.868377 & -4.789180 & -0.360486 \\
\hline $\mathrm{H}$ & 0.554225 & -4.948664 & -2.368877 \\
\hline $\mathrm{H}$ & 0.570597 & -5.670159 & -0.772736 \\
\hline $\mathrm{H}$ & 0.735755 & -3.427755 & 0.285968 \\
\hline $\mathrm{O}$ & -1.704029 & -3.998012 & -1.766901 \\
\hline $\mathrm{N}$ & -1.723746 & -2.733800 & 0.126026 \\
\hline $\mathrm{H}$ & -1.148377 & -2.213952 & 0.789638 \\
\hline $\mathrm{H}$ & -3.489519 & -3.014744 & -0.838819 \\
\hline $\mathrm{H}$ & -3.865475 & -3.761169 & 1.437803 \\
\hline
\end{tabular}




\begin{tabular}{crrr}
$\mathrm{H}$ & -3.574602 & -2.134613 & 2.075596 \\
$\mathrm{H}$ & -5.856452 & -2.963482 & 0.212814 \\
$\mathrm{H}$ & -6.007321 & -2.503471 & 1.906655 \\
$\mathrm{H}$ & -6.624546 & -0.606586 & 0.394650 \\
$\mathrm{H}$ & -5.204763 & -0.198282 & 1.358732 \\
$\mathrm{H}$ & -4.886421 & 0.436171 & -1.054646 \\
$\mathrm{H}$ & -5.155518 & -1.243563 & -1.522895 \\
$\mathrm{H}$ & -2.750730 & -0.837875 & -1.472438 \\
$\mathrm{O}$ & -2.331547 & -0.193165 & 1.606249 \\
$\mathrm{~N}$ & -2.585876 & 1.345947 & -0.028413 \\
$\mathrm{H}$ & -2.607846 & 1.489933 & -1.034857 \\
$\mathrm{H}$ & -1.158472 & 2.165235 & 1.254100 \\
$\mathrm{H}$ & -3.283977 & 1.899136 & 2.507025 \\
$\mathrm{H}$ & -2.680569 & 3.559532 & 2.542125 \\
$\mathrm{H}$ & -4.914395 & 2.507834 & 0.725970 \\
$\mathrm{H}$ & -5.135696 & 3.559362 & 2.122261 \\
$\mathrm{H}$ & -5.150865 & 4.869101 & -0.020613 \\
$\mathrm{H}$ & -3.818633 & 5.351923 & 1.024749 \\
$\mathrm{H}$ & -3.622771 & 3.459615 & -1.383179 \\
$\mathrm{H}$ & -3.001980 & 5.096788 & -1.303272 \\
$\mathrm{H}$ & -1.440360 & 4.462291 & 0.508427 \\
$\mathrm{O}$ & -1.284728 & 2.681562 & -2.219371 \\
$\mathrm{~N}$ & 0.382493 & 3.579881 & -0.945602 \\
$\mathrm{H}$ & 0.608372 & 3.956645 & -0.031913 \\
$\mathrm{H}$ & -1.066515 & -2.365602 & 3.614338 \\
$\mathrm{H}$ & -1.454653 & -2.736187 & 4.563697 \\
$\mathrm{H}$ & -1.772137 & -1.665719 & 3.161394 \\
$\mathrm{H}$ & -0.922853 & -3.210089 & 2.933873 \\
$\mathrm{H}$ & 2.192682 & 2.716890 & -2.646340 \\
$\mathrm{H}$ & 2.816520 & 4.524346 & -2.408841 \\
$\mathrm{H}$ & 3.703370 & 3.237792 & -0.805338 \\
$\mathrm{H}$ & 4.642205 & 4.360714 & -2.443188 \\
$\mathrm{H}$ & 5.340868 & 1.993839 & -2.030375 \\
$\mathrm{H}$ & 4.638383 & 2.706028 & -0.575844 \\
$\mathrm{H}$ & 3.722464 & 0.398118 & -1.010667 \\
$\mathrm{H}$ & 3.140787 & 0.930010 & -2.588797 \\
$\mathrm{H}$ & 1.278463 & 0.968116 & -1.126863 \\
$\mathrm{O}$ & 2.240643 & 3.039561 & 1.101379 \\
$\mathrm{H}$ & 2.298065 & 0.781331 & 1.247609 \\
$\mathrm{H}$ & 1.976096 & -0.076482 & 0.808702 \\
$\mathrm{H}$ & 1.607579 & 1.383662 & 3.123477 \\
$\mathrm{H}$ & 3.826504 & 2.405219 & 2.760281 \\
$\mathrm{H}$ & 3.774269 & 1.434644 & 4.235738 \\
$\mathrm{H}$ & 5.887532 & 0.988715 & 2.988424 \\
$\mathrm{H}$ & 5.6635971812 & 0.545567 & 1.555012 \\
$\mathrm{H}$ & 3.403551 & -1.508469 & 2.770607 \\
$\mathrm{H}$ & -2.535427 & 4.251432 \\
\hline
\end{tabular}




\section{References}

(S1) Schinnerl, M.; Murray, J. K.; Langenhan, J. M.; Gellman, S. H. Eur. J. Org. Chem. 2003, 2003, 721.

(S2) Lee, M.; Shim, J.; Kang, P.; Choi, M.-G.; Choi, S. H. Chem. Commun. 2016, 52, 5950.

(S3) Bruker-AXS. (2007-2014) APEX2 (Ver. 2014.1-1), SADABS (2012-1), and SAINT+ (Ver. 8.32A) Software Reference Manuals. Bruker-AXS: Madison, WI.

(S4) (a) Sheldrick, G. M. Acta Cryst. A 2008, 64, 112; (b) Dolomanov, O. V.; Bourhis, L. J.; Gildea, R. J.; Howard, J. A. K.; Puschmann, H. J. Appl. Cryst. 2009, 42, 339; (c) Guzei, I. A. Programs Gn.; University of WisconsinMadison: Madison, WI, 2007-2014.

(S5) Spek, A. Acta Cryst. C 2015, 71, 9.

(S6) Krause, L.; Herbst-Irmer, R.; Sheldrick, G. M.; Stalke, D. J. Appl. Cryst. 2015, 48, 3.

(S7) (a) Sheldrick, G. M. Acta Cryst. C 2015, 71, 3; (b) Sheldrick, G. M. Acta Cryst. A 2015, 71, 3; (c) Sheldrick, G. M. The SHELX homepage, http://shelx.uni-ac.gwdg.de/SHELX, 2013.

(S8) Zhao, Y.; Truhlar, D. G. Theor. Chem. Acc. 2008, 120, 215.

(S9) Frisch, M. J.; Trucks, G. W.; Schlegel, H. B.; Scuseria, G. E.; Robb, M. A.; Cheeseman, J. R.; Scalmani, G.; Barone, V.; Mennucci, B.; Petersson, G. A.; Nakatsuji, H.; Caricato, M.; Li, X.; Hratchian, H. P.; Izmaylov, A. F.; Bloino, J.; Zheng, G.; Sonnenberg, J. L.; Hada, M.; Ehara, M.; Toyota, K.; Fukuda, R.; Hasegawa, J.; Ishida, M.; Nakajima, T.; Honda, Y.; Kitao, O.; Nakai, H.; Vreven, T.; Montgomery Jr., J. A.; Peralta, J. E.; Ogliaro, F.; Bearpark, M. J.; Heyd, J.; Brothers, E. N.; Kudin, K. N.; Staroverov, V. N.; Kobayashi, R.; Normand, J.; Raghavachari, K.; Rendell, A. P.; Burant, J. C.; Iyengar, S. S.; Tomasi, J.; Cossi, M.; Rega, N.; Millam, N. J.; Klene, M.; Knox, J. E.; Cross, J. B.; Bakken, V.; Adamo, C.; Jaramillo, J.; Gomperts, R.; Stratmann, R. E.; Yazyev, O.; Austin, A. J.; Cammi, R.; Pomelli, C.; Ochterski, J. W.; Martin, R. L.; Morokuma, K.; Zakrzewski, V. G.; Voth, G. A.; Salvador, P.; Dannenberg, J. J.; Dapprich, S.; Daniels, A. D.; Farkas, Ö.; Foresman, J. B.; Ortiz, J. V.; Cioslowski, J.; Fox, D. J. Gaussian 09, Revision A.02; Gaussian, Inc.: Wallingford, CT, USA, 2009.

(S10) Mandity, I. M.; Fulop, L.; Vass, E.; Toth, G. K.; Martinek, T. A.; Fulop, F. Org. Lett. 2010, 12, 5584.

(S11) Mennucci, B.; Cammi, R.; Tomasi, J. J. Chem. Phys. 1999, 110, 6858. 